\title{
Assessment of the Performance of CORDEX Regional Climate Models in Simulating East African Rainfall
}

\author{
Hussen Seid Endris, ${ }^{\mathrm{a}}$ Philip OMOndi, ${ }^{\mathrm{b}}$ Suman Jain, ${ }^{\mathrm{c}}$ Christopher Lennard, ${ }^{\mathrm{a}}$ Bruce Hewitson, ${ }^{\mathrm{a}}$ \\ Ladislaus Chang'A, ${ }^{\mathrm{d}}$ J. L. Awange, ${ }^{\mathrm{e}}$ Alessandro Dosio, ${ }^{\mathrm{f}}$ PATrick Ketiem, ${ }^{\mathrm{g}}$ \\ Grigory NikUlin, ${ }^{\mathrm{h}}$ HANS-JÜrgen PANITZ, ${ }^{\mathrm{i}}$ MATTHIAS BÜCHNER, ${ }^{\mathrm{j}}$ \\ FRODE STORDAL, ${ }^{\mathrm{k}}$ AND LUKIYA TAZALIKA ${ }^{1}$ \\ ${ }^{a}$ University of Cape Town, Cape Town, South Africa \\ ${ }^{\mathrm{b}}$ IGAD Climate Prediction and Applications Centre, Nairobi, Kenya \\ ${ }^{\mathrm{c}}$ University of Zambia, Lusaka, Zambia \\ ${ }^{\mathrm{d}}$ Tanzania Meteorological Agency, Dar es Salaam, Tanzania \\ ${ }^{\mathrm{e}}$ Western Australian Centre for Geodesy and the Institute for Geoscience Research, Curtin University, Perth, Australia \\ ${ }^{\mathrm{f}}$ European Commission Joint Research Centre, Institute for Environment and Sustainability, Ispra, Italy \\ ${ }^{\mathrm{g}}$ Kenya Agricultural Research Institute, Nairobi, Kenya \\ ${ }^{\mathrm{h}}$ Rossby Centre, Swedish Meteorological and Hydrological Institute, Norrköping, Sweden \\ ${ }^{\mathrm{i}}$ Institut für Meteorologie und Klimaforschung, and Karlsruher Institut für Technologie, Karlsruhe, Germany \\ ${ }^{\mathrm{j}}$ Potsdam Institute for Climate Impact Research, Potsdam, Germany \\ ${ }^{\mathrm{k}}$ University of Oslo, Oslo, Norway \\ ${ }^{1}$ Uganda Meteorological Department, Kampala, Uganda
}

(Manuscript received 2 October 2012, in final form 7 May 2013)

\begin{abstract}
This study evaluates the ability of 10 regional climate models (RCMs) from the Coordinated Regional Climate Downscaling Experiment (CORDEX) in simulating the characteristics of rainfall patterns over eastern Africa. The seasonal climatology, annual rainfall cycles, and interannual variability of RCM output have been assessed over three homogeneous subregions against a number of observational datasets. The ability of the RCMs in simulating large-scale global climate forcing signals is further assessed by compositing the El Niño-Southern Oscillation (ENSO) and Indian Ocean dipole (IOD) events. It is found that most RCMs reasonably simulate the main features of the rainfall climatology over the three subregions and also reproduce the majority of the documented regional responses to ENSO and IOD forcings. At the same time the analysis shows significant biases in individual models depending on subregion and season; however, the ensemble mean has better agreement with observation than individual models. In general, the analysis herein demonstrates that the multimodel ensemble mean simulates eastern Africa rainfall adequately and can therefore be used for the assessment of future climate projections for the region.
\end{abstract}

\section{Introduction}

The rainfall pattern over eastern Africa is highly variable both in space and time. The region is already witnessing dire consequences of erratic climatic conditions that are likely to be associated with regional climate change (FEWS NET 2011; Anyah and Qiu 2012). The

Corresponding author address: Hussen Seid Endris, Climate System Analysis Group, University of Cape Town, Cape Town, South Africa.

E-mail: hussen.seid1@gmail.com region experiences serious food insecurity and resourcebased conflicts in addition to recurring droughts and floods that have dramatic socioeconomic impacts (UNEP 2011; World Bank 2012). The 2007 Intergovernmental Panel on Climate Change (IPCC) report provided clear evidence of climate change in the region with increased risks of climate extremes. The economies and livelihoods of people in the majority of countries in the region still rely on rain-dependent systems and so are vulnerable to current rainfall variability and potential changes in rainfall due to climate change. Recent economic assessments (World Bank 2012) show that no 
TABLE 1. List of RCMs used and their details (Source: Nikulin et al. 2012).

\begin{tabular}{|c|c|c|c|c|}
\hline & $\begin{array}{l}\text { CNRM Action de } \\
\text { Recherche Petite } \\
\text { Échelle Grande } \\
\text { Échelle (ARPEGE) } 5.1\end{array}$ & DMI HIRHAM5 & $\begin{array}{l}\text { ICTP regional climate } \\
\text { model version } 3 \\
\text { (RegCM3) }\end{array}$ & $\begin{array}{c}\text { CLMcom } \\
\text { COSMO-CLM } \\
(\text { CCLM) version } 4.8\end{array}$ \\
\hline Institute & $\begin{array}{l}\text { Centre National de } \\
\text { Recherches } \\
\text { Météorologiques } \\
\text { (CNRM), France }\end{array}$ & $\begin{array}{l}\text { Danmarks } \\
\text { Meteorologiske } \\
\text { Institut (DMI), } \\
\text { Danmark }\end{array}$ & $\begin{array}{l}\text { Abdus Salam } \\
\text { International } \\
\text { Centre for Theoretical } \\
\text { Physics (ICTP), Italy }\end{array}$ & $\begin{array}{l}\text { Climate Limited-Area } \\
\text { Modelling (CLM) } \\
\text { Community (www. } \\
\text { clm-community.eu) }\end{array}$ \\
\hline Short name & ARPEGE & HIRHAM & RegCM3 & CCLM \\
\hline Projection resolution & $\begin{array}{l}\text { Polar, stretching } \\
\text { factor } 2 \text { (tl179) }\end{array}$ & Rotated pole $0.44^{\circ}$ & Mercator $50 \mathrm{~km}$ & Rotated pole $0.44^{\circ}$ \\
\hline $\begin{array}{l}\text { Vertical } \\
\text { coordinate/levels }\end{array}$ & Hybrid/31 & Hybrid/31 & Sigma/18 & Terrain following/35 \\
\hline Advection & Semi-Lagrangian & Semi-Lagrangian & Eulerian & $\begin{array}{l}\text { Fifth-order upwind; } \\
\text { Baldauf (2008) }\end{array}$ \\
\hline Time step (s) & 1200 & 600 & 100 & 240 \\
\hline Convective scheme & Bougeault (1985) & Tiedtke (1989) & $\begin{array}{l}\text { Grell (1993); Fritsch } \\
\text { and Chappell (1980) }\end{array}$ & Tiedtke (1989) \\
\hline Radiation scheme & Morcrette (1990) & $\begin{array}{l}\text { Fouquart and Bonnel } \\
\text { (1980); Mlawer et al. } \\
\text { (1997) }\end{array}$ & Kiehl et al. (1996) & $\begin{array}{l}\text { Ritter and Geleyn } \\
\quad(1992)\end{array}$ \\
\hline $\begin{array}{l}\text { Turbulence vertical } \\
\text { diffusion }\end{array}$ & $\begin{array}{l}\text { Mellor and Yamada } \\
\quad(1982)\end{array}$ & Louis (1979) & Holtslag et al. (1990) & $\begin{array}{l}\text { Herzog et al. (2002); } \\
\text { Buzzi et al. (2011) }\end{array}$ \\
\hline $\begin{array}{l}\text { Cloud microphysics } \\
\text { scheme }\end{array}$ & $\begin{array}{l}\text { Ricard and Royer } \\
\text { (1993) }\end{array}$ & $\begin{array}{l}\text { Tiedtke (1989); } \\
\text { Tompkins (2002) }\end{array}$ & $\begin{array}{l}\text { Subgrid explicit } \\
\text { moisture scheme } \\
\text { (SUBEX); Pal } \\
\text { et al. }(2000)\end{array}$ & $\begin{array}{l}\text { Doms et al. (2007); } \\
\text { Baldauf and Schulz } \\
\text { (2004) }\end{array}$ \\
\hline Land surface scheme & $\begin{array}{l}\text { ISBA; Douville et al. } \\
\quad(2000)\end{array}$ & $\begin{array}{l}\text { Schulz et al. (1998); } \\
\text { Hagemann (2002) }\end{array}$ & $\begin{array}{l}\text { BATS1E; Dickinson } \\
\text { et al. (1993) }\end{array}$ & $\begin{array}{l}\text { TERRA-ML; Doms } \\
\text { et al. (2007) }\end{array}$ \\
\hline $\begin{array}{l}\text { Latest reference } \\
\text { and comments }\end{array}$ & Déqué (2010) & $\begin{array}{l}\text { Christensen et al. } \\
\text { (2006) }\end{array}$ & Pal et al. (2007) & $\begin{array}{l}\text { Rockel et al. (2008); } \\
\text { Baldauf et al. (2011) }\end{array}$ \\
\hline
\end{tabular}

sustainable development can be attained in the region without effective regional systems for climate risk reduction including climate change adaptation.

Global climate models (GCMs) are suitable tools for the assessment of climate variability and change. Current GCMs have spatial resolution on the order of 100 $250 \mathrm{~km}$ and have the potential to simulate the main characteristics of general circulation at the range of this scale (Shongwe et al. 2009). Although GCMs can satisfactorily simulate the atmospheric general circulation at the continental scale, they are not necessarily capable of capturing the detailed processes associated with regionallocal climate variability and changes that are required for regional and national climate change assessments (Giorgi and Mearns 1999; Denis et al. 2002; Wang et al. 2004; Giorgi et al. 2009; Rummukainen 2010). This is particularly true for heterogeneous regions such as eastern
Africa, where sub-GCM gridscale variations in topography, vegetation, soils, and coastlines have a significant effect on the climate. In addition, at coarse grid resolutions, the magnitude and intensity of subgrid-scale extreme events such as heavy rainfall (leading to floods) are often not captured, nor realistically reproduced. Generally, GCM data have been used to describe the climate processes of many African regions and to produce the climate information for applications in different socioeconomic sectors including agriculture, water, and health (Alley et al. 2007). However, in order to formulate adaptation policies in response to climate change impacts, reliable climate change information is usually required at finer spatial scales than that of a typical GCM.

Regional climate models (RCMs) dynamically downscale GCM output to scales more suited to end users (Sun et al. 2006) and are useful for understanding local climate 
TABLE 1. (Extended)

\begin{tabular}{|c|c|c|c|c|c|}
\hline $\begin{array}{l}\text { KNMI Regional } \\
\text { Atmospheric Climate } \\
\text { Model, version } 2.2 \\
\text { (RACMO2.2b) }\end{array}$ & $\begin{array}{c}\text { MPI regional } \\
\text { model (REMO) }\end{array}$ & $\begin{array}{l}\text { SMHI Rossby } \\
\text { Center Regional } \\
\text { Atmospheric } \\
\text { Model (RCA35) }\end{array}$ & $\begin{array}{l}\text { UCT Providing } \\
\text { Regional } \\
\text { Climates for } \\
\text { Impacts Studies } \\
\text { (PRECIS) }\end{array}$ & $\begin{array}{c}\text { UC Weather } \\
\text { Research and } \\
\text { Forecasting Model } \\
\text { version 3.1.1. } \\
\text { (WRF3.1.1) }\end{array}$ & $\begin{array}{c}\text { UQAM } \\
\text { fifth-generation } \\
\text { Canadian Regional } \\
\text { Climate Model } \\
\text { (CRCM5) }\end{array}$ \\
\hline $\begin{array}{l}\text { Koninklijk } \\
\text { Nederlands } \\
\text { Meteorologisch } \\
\text { Instituut (KNMI), } \\
\text { Netherlands }\end{array}$ & $\begin{array}{l}\text { Max Planck } \\
\text { Institute (MPI), } \\
\text { Germany }\end{array}$ & $\begin{array}{l}\text { Sveriges } \\
\text { Meteorologiska } \\
\text { och Hydrologiska } \\
\text { Institut (SMHI), } \\
\text { Sweden }\end{array}$ & $\begin{array}{l}\text { University of Cape } \\
\text { Town (UCT), } \\
\text { South Africa }\end{array}$ & $\begin{array}{l}\text { Universidad de } \\
\text { Cantabria, Spain }\end{array}$ & $\begin{array}{l}\text { Université du } \\
\text { Québec à } \\
\text { Montréal } \\
\text { (UQAM), } \\
\text { Canada }\end{array}$ \\
\hline RACMO & REMO & RCA & PRECIS & WRF & CRCM \\
\hline Rotated pole $0.44^{\circ}$ & Rotated pole $0.44^{\circ}$ & Rotated pole $0.44^{\circ}$ & Rotated pole $0.44^{\circ}$ & Mercator $50 \mathrm{~km}$ & $\begin{array}{l}\text { Rotated pole } \\
0.44^{\circ}\end{array}$ \\
\hline Hybrid/40 & Hybrid/27 & Hybrid/40 & Hybrid/19 & $\begin{array}{l}\text { Terrain following } \\
\text { ETA } / 28\end{array}$ & Hybrid/56 \\
\hline Semi-Lagrangian & Semi-Lagrangian & Semi-Lagrangian & Eulerian & Eulerian & Semi-Lagrangian \\
\hline 720 & 240 & 1200 & 300 & 240 & 1200 \\
\hline Tiedtke (1989) & Tiedtke (1989) & $\begin{array}{l}\text { Kain and Fritsch } \\
(1990,1993)\end{array}$ & $\begin{array}{l}\text { Gregory and } \\
\text { Rowntree } \\
\text { (1990); Gregory } \\
\text { and Allen (1991) }\end{array}$ & Kain (2004) & $\begin{array}{l}\text { Kain and Fritsch } \\
\quad(1990) ; \text { Kuo (1965) }\end{array}$ \\
\hline $\begin{array}{l}\text { Fouquart and } \\
\text { Bonnel (1980) }\end{array}$ & $\begin{array}{l}\text { Morcrette et al. } \\
\text { (1986); Giorgetta } \\
\text { and Wild (1995) }\end{array}$ & $\begin{array}{l}\text { Savijärvi (1990); } \\
\quad \text { Sass et al. (1994) }\end{array}$ & $\begin{array}{l}\text { Edwards and } \\
\text { Slingo (1996) }\end{array}$ & $\begin{array}{l}\text { Dudhia (1989); } \\
\text { Mlawer et al. (1997) }\end{array}$ & $\begin{array}{l}\text { Li and Barker } \\
\quad(2005)\end{array}$ \\
\hline $\begin{array}{l}\text { Eddy-diffusivity } \\
\text { (first-order K) } \\
\text { mass flux approach }\end{array}$ & Louis (1979) & Cuxart et al. (2000) & Wilson (1992) & Hong et al. (2006) & $\begin{array}{l}\text { Benoit et al. (1989); } \\
\text { Delage (1997) }\end{array}$ \\
\hline Tiedtke (1993) & $\begin{array}{l}\text { Lohmann and } \\
\text { Roeckner (1996) }\end{array}$ & $\begin{array}{l}\text { Rasch and } \\
\text { Kristjánsson } \\
\text { (1998) }\end{array}$ & Smith (1990) & $\begin{array}{l}\text { WRF single-moment } \\
\text { 5-class microphysics } \\
\text { scheme (WSM5); } \\
\text { Hong et al. (2004) }\end{array}$ & $\begin{array}{l}\text { Sundqvist et al. } \\
\text { (1989) }\end{array}$ \\
\hline $\begin{array}{l}\text { TESSEL; ECMWF } \\
\text { (2006) }\end{array}$ & $\begin{array}{l}\text { Hagemann (2002) } \\
\text { Rechid et al. } \\
(2009)\end{array}$ & $\begin{array}{l}\text { Samuelsson et al. } \\
\quad(2006)\end{array}$ & $\begin{array}{l}\text { MOSES2; Essery } \\
\text { et al. (2003) }\end{array}$ & Smirnova et al. (2000) & $\begin{array}{l}\text { CLASS 3.5; } \\
\text { Verseghy (2000) }\end{array}$ \\
\hline $\begin{array}{l}\text { van Meijgaard et al. } \\
\text { (2008); based on } \\
\text { ECMWF cycle } \\
\text { 31r1; ECMWF } \\
(2006)\end{array}$ & $\begin{array}{l}\text { Jacob (2001) Jacob } \\
\text { et al. (2007) }\end{array}$ & $\begin{array}{l}\text { Samuelsson et al. } \\
\quad(2011)\end{array}$ & Jones et al. (2004) & $\begin{array}{l}\text { Skamarock et al. } \\
\text { (2008) }\end{array}$ & Zadra et al. (2008) \\
\hline
\end{tabular}

in regions that have complex topography such as eastern Africa. Globally, there has been a marked increase in the number of RCM simulations (Alley et al. 2007); however, very few RCM studies have been performed over the East African region (Sun et al. 1999a; Indeje et al. 2000; Anyah, 2005; Anyah et al. 2006; Anyah and Semazzi 2006; Anyah and Semazzi, 2007; Segele et al. 2009a; Diro et al. 2012), and these studies are largely based on the results from a single RCM. However, each model has its strengths and weaknesses. Thus, the application of a set of RCMs is needed, but this has not been done before because of the lack of a large ensemble of RCM output.

Currently, the Coordinated Regional Climate Downscaling Experiment (CORDEX) program, initiated by the World Climate Research Program, provides an opportunity for generating high-resolution regional climate projections, which can be used for assessment of the future impacts of climate change at regional scales (Giorgi et al. 2009). However, the ability of the RCMs has to be assessed before they are used for generating downscaled projections of the future climate.

This study aims to assess the performance of the CORDEX RCMs (Table 1) in simulating the current rainfall characteristics over the East African region defined as the area lying within $16^{\circ} \mathrm{S}-18^{\circ} \mathrm{N}, 22^{\circ}-52^{\circ} \mathrm{E}$ (Fig. 1). We also investigate the ability of the RCMs to capture the influence of the large-scale climate circulation patterns (teleconnections) on regional rainfall. The research focuses on the selected East African CORDEX subregions (Fig. 1) that have been classified on the basis of their rainfall distribution as delineated by Favre et al. (2011). The seasons chosen for study are June-September (JJAS) for the northern sector and October-December (OND) for the equatorial and southern sectors. Previous 
studies (Indeje et al. 2000; Mutemi 2003; Nyakwada 2009) show that the long rainfall season over the equatorial sector that occurs in March-May (MAM) is dominated by local factors rather than large-scale factors in the modulation of rainfall patterns. Relative to the long rains, the short rains tend to have stronger interannual variability, stronger spatial coherence of rainfall anomalies across a large part of the region, and a substantial association with ENSO and the Indian Ocean dipole (IOD) (e.g., Ropelewski and Halpert 1987, 1989; Ogallo 1988; Hastenrath et al. 1993; Nicholson and Kim 1997; Saji et al. 1999; Indeje et al. 2000; Mutemi 2003; Nyakwada 2009). Also, OND is the common rainfall season for both equatorial and southern parts of the eastern Africa. Consequently, our study focuses on JJAS for the northern sector and OND for the equatorial and southern sectors only.

The study is organized as follows: in section 2, we present a brief description of the study area, datasets, and methodology used. In section 3, we present the results and discussion beginning with the climatology, mean annual cycle, interannual variability, and the response of ENSO and IOD to regional rainfall anomalies. Finally in section 4, we summarize the key results and present our conclusions.

\section{Data and methodology}

\section{a. Study region}

Our study focuses on the CORDEX eastern African region, which refers to the countries of the Greater Horn of Africa (GHA), namely, Burundi, Djibouti, Eritrea, Ethiopia, Kenya, Rwanda, Somalia, Sudan, South Sudan, Tanzania, and Uganda (Fig. 1). The region has a complex topography and is characterized by different rainfall regimes. Local factors such as complex terrain and land surface heterogeneity and their consequent interactions with large-scale climate forcing mechanisms contribute to the diverse spatial rainfall patterns over the region. The climatological annual rainfall cycle in much of eastern Africa is strongly linked to the northsouth movement of the intertropical convergence zone (ITCZ). The assessment is performed over three subregions of the domain (Fig. 1), which are hereafter referred to as NEA (northern East Africa; $7.25^{\circ}-15.25^{\circ} \mathrm{N}$, $33.75^{\circ}-40.25^{\circ} \mathrm{E}$ ), EEA (eastern East Africa; $2.25^{\circ}-11.75^{\circ} \mathrm{N}$, $44.25^{\circ}-51.75^{\circ} \mathrm{E}$ ), and SEA (southern East Africa; $2.25^{\circ}-$ $15.25^{\circ} \mathrm{S}, 28.75^{\circ}-35.25^{\circ} \mathrm{E}$ ). These subregions have been chosen based on previous studies that classified CORDEXAfrica into 15 homogeneous subregions based on observed Global Precipitation Climatology Centre (GPCC) rainfall data (Favre et al. 2011), and also they are representative

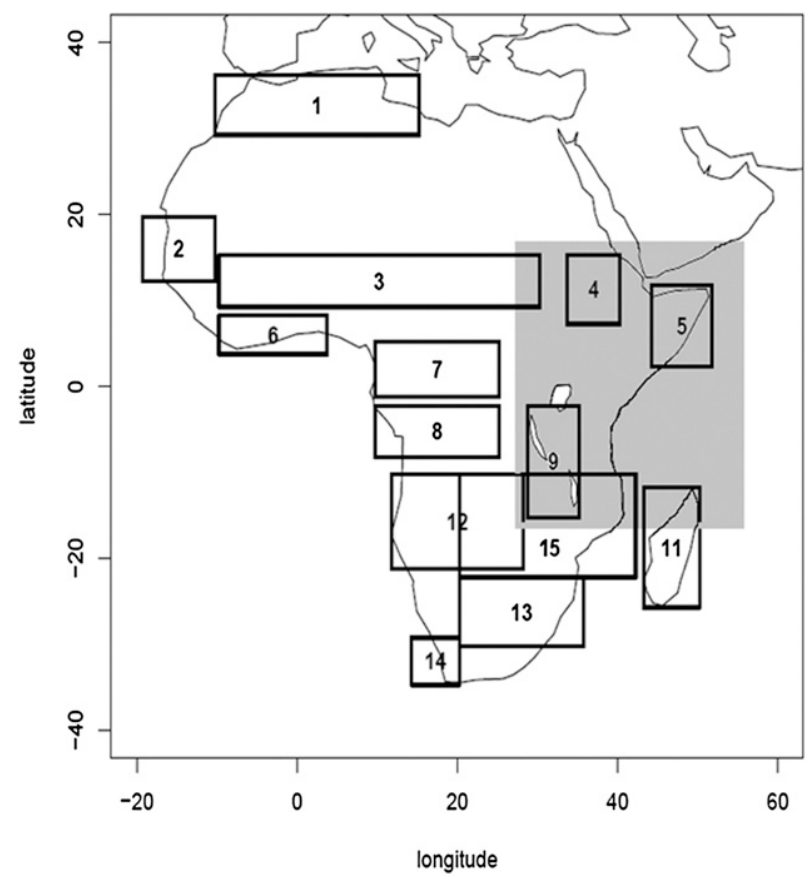

FIG. 1. Map of the study area (greater Horn of Africa), with three subregions represented by boxes 4 (NEA), 5 (EEA), and 9 (SEA) that are utilized for analysis (Favre et al. 2011).

of different rainfall patterns over East Africa associated with different mechanisms.

NEA (region 4) covers the Ethiopian highlands, which exhibit a unimodal rainfall pattern between June and September. EEA (region 5) covers the eastern equatorial parts of East Africa and is characterized by a bimodal rainfall distribution with the major rainfall season in March-May and a shorter rainfall season in OctoberDecember. SEA (region 9) covers the southern part of eastern Africa and is mainly characterized by unimodal rainfall distribution spanning from November to April.

\section{b. Data}

\section{1) RCM DATA}

In this study, we used simulated monthly rainfall data from 10 CORDEX RCMs. The RCMs were forced by lateral and surface boundary conditions from the European Centre for Medium-Range Weather Forecasts (ECMWF) Interim Re-Analysis (ERA-Interim), and downscaled data are available for the period 1989-2008. All simulations were performed at $\sim 50 \mathrm{~km}\left(0.44^{\circ}\right)$ resolution over the CORDEX-Africa domain. Table 1 presents a full list of the RCMs used (with full expansions) and the details of their dynamics and their physical parameterizations. More information on model output can be obtained from Nikulin et al. (2012). This paper uses the short names for the CORDEX RCMs. 
TABLE 2. Classification of ENSO and IOD zonal node (IODZM) events from 1989 to 2008 during the two seasons of study (source: http:// www.marine.csiro.au/ mcintosh/Research_ENSO_IOD_years.htm).

\begin{tabular}{|c|c|c|c|c|c|}
\hline $\begin{array}{l}\text { Pure negative } \\
\text { IODZM }\end{array}$ & Pure La Niña & $\begin{array}{l}\text { Pure positive } \\
\text { IODZM }\end{array}$ & Pure El Niño & $\begin{array}{l}\text { Co-occurrence of El Niño } \\
\text { and positive IODZM }\end{array}$ & $\begin{array}{l}\text { Co-occurrence of La Niña } \\
\text { and negative IODZM }\end{array}$ \\
\hline 1989 & 1998 & 1994 & & 1991 & \\
\hline 1992 & $\begin{array}{l}1999 \\
2007\end{array}$ & 2004 & & 1997 & \\
\hline
\end{tabular}

\section{2) OBSERVED DATA}

Generally, Africa lacks high-quality observation datasets at suitable temporal and spatial resolution necessary for evaluating RCM simulations. Sylla et al. (2012) presented an intercomparison of different observed daily precipitation datasets and a validation exercise of a regional climate model simulation (with the RegCM3 model). They found that substantial discrepancies exist among the different observational datasets, and this makes it difficult to assess the model performance. Similarly, Nikulin et al. (2012) show large differences between satellite and gauge-based products.

For this study, model results are compared against three observational datasets. Two gauge-based gridded observational datasets are used that are available at $0.5^{\circ}$ spatial and monthly temporal resolution: the Global Precipitation Climatology Centre (version 5, 1901-2006; Rudolf et al. 2010) and Climatic Research Unit (CRU) (version 3.0, 1901-2006; Mitchell and Jones 2005). Furthermore, satellite-gauge combined dataset from the Global Precipitation Climatology Project (GPCP; version 2.2; http://www.esrl.noaa.gov/psd/data/gridded/data.gpcp.html) is used even though the resolution is coarse $\left(2.5^{\circ}\right)$.

GPCC data are chosen as a reference field to evaluate the performance of CORDEX RCMs in the context of rainfall over the region. The choice of GPCC data is based on its sufficiently long time series that cover the period (1989-2008) of simulated data. Other advantages are that the GPCC dataset has same resolution as the RCMs' simulated data, and as stated earlier the regions used in the analysis were classified based on GPCC data. ERA-Interim reanalysis data were not used as a comparison field since CORDEX RCMs are forced by ERA-Interim reanalysis and therefore there may be autocorrelation between the ERA-Interim precipitation field and the simulated precipitation fields. However, because of the lack of high-resolution wind data over the continent to compare the circulation pattern, ERAInterim wind field data are used as comparison fields.

\section{3) DAta Limitations}

The data used in this analysis were produced by many different downscaling groups (see Table 1). These data were generally received in the native model format, projection, and grid and thus had to be postprocessed into a common data format with the same horizontal and vertical dimensions. This enormous task was performed at the Sveriges Meteorologiska och Hydrologiska Institut (SMHI), Sweden, and the institute also served as the repository for the postprocessed data. An initial set of diagnostic variables were processed by the SMHI at the start of the CORDEX-Africa analysis initiative, which started in 2011; however, as the analysis progressed additional prognostic variables were desired to understand the downscaled results (e.g., winds at particular levels to examine the presence of jets). Unfortunately these variables (except $850-\mathrm{hPa}$ level wind) could not be made available at a later stage by all centers (for reasons such as space and deletion) so subsequently some variables were not available for inclusion in the analysis. It was therefore not possible to assess the dynamical drivers at different level of observed biases in the RCMs despite the desire to do so.

\section{c. Methodology}

We adopted two general criteria to assess the ability of CORDEX RCMs to simulate East African rainfall. The first criterion assesses the ability of the RCMs to reproduce the rainfall climatology. The second criterion assesses the ability of the RCMs to capture the interannual rainfall variability and teleconnection signals. Brief descriptions of each assessment are given below.

In the first assessment of rainfall climatology, a number of tests are performed. Comparison of observed and simulated seasonal mean rainfall climatology over the entire East African region is done to examine the ability of RCMs to capture the spatial distribution of rainfall. A paired difference Student's $t$ test for hypothesis of zero difference between the mean of simulated and observed seasonal rainfall at $5 \%$ level of significance is applied for each subregion to detect significant differences in the two means. To assess the consistency of the models in representing the spatial distribution of rainfall with time, spatial correlation between observed and simulated rainfall is computed for each year. The annual cycle of rainfall, area averaged for each region, is computed for both observed and simulated data to determine how well the RCMs capture rainfall seasonality in the respective regions. 
(a)
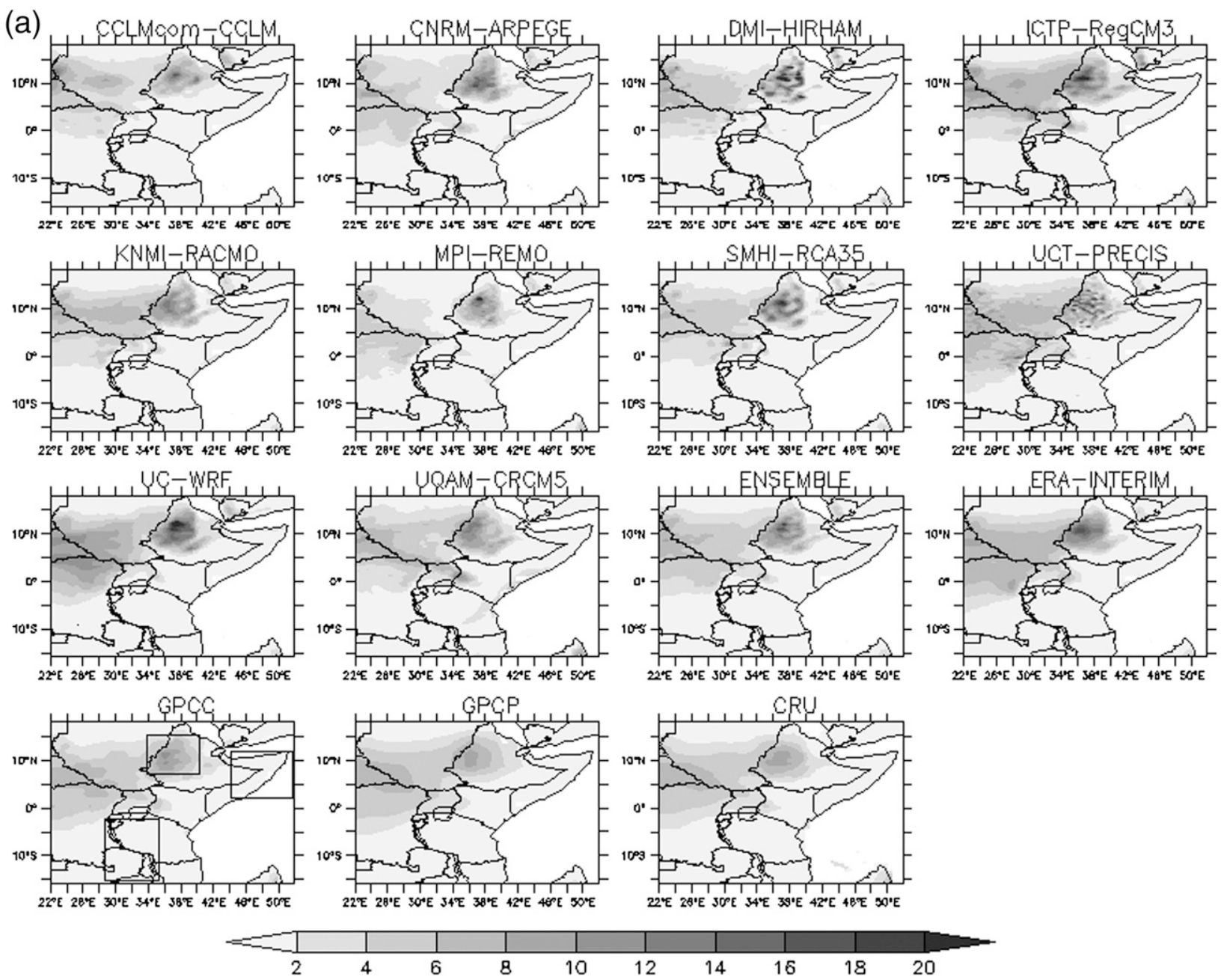

FIG. 2. (a) Climatology of rainfall in eastern Africa during JJAS as simulated by (top two and a half rows) the 10 CORDEX RCMs, (third row, last two panels) ensemble and ERA-Interim, and (bottom) observation (GPCC, GPCP, and CRU). All in mm day ${ }^{-1}$. (b) As in (a), but for OND.

A Taylor diagram (Taylor 2001) is used to evaluate the spatiotemporal pattern errors (i.e., "centered" errors) in the model results. The diagram characterizes the statistical relationship between two fields, a "test" field (often representing a field simulated by a model) and a "reference" field (usually representing "truth," based on observations). In the diagram, the distance from the origin is equal to the standard deviation, while the distance from the reference point (GPCC in this case) is the equal root-mean-square (RMS) difference between the reference and test fields, and the cosine of the polar angle is equal to the correlation. A "perfect" model under this definition would have no error as computed by the rootmean-square. It would perfectly correlate with the observed data, and would have the same standard deviation. Thus, "skill" measures correspondence among patterns, trends, and variability in the model and observations. Note that the means of the fields are subtracted out before computing their second-order statistics, so the diagram does not provide information about overall biases, but solely characterizes the centered pattern error. These statistics are related by the following equation:

$$
E^{\prime 2}=\sigma_{f}^{2}+\sigma_{r}^{2}-2 \sigma_{f} \sigma_{r} R
$$

where $R$ is the correlation coefficient between the model $(f)$ and observed $(r)$ given by Eq. (2);

$$
R=\frac{\frac{1}{N} \sum_{n=1}^{N}\left(f_{n}-\bar{f}\right)\left(r_{n}-\bar{r}\right)}{\sigma_{f} \sigma_{r}},
$$

where $N$ is the number of data points in the model and observed fields, whereas $\sigma_{f}^{2}$ and $\sigma_{r}^{2}$ are the variances of the model and reference fields given respectively by Eqs. (4a) and (4b). 
(b)
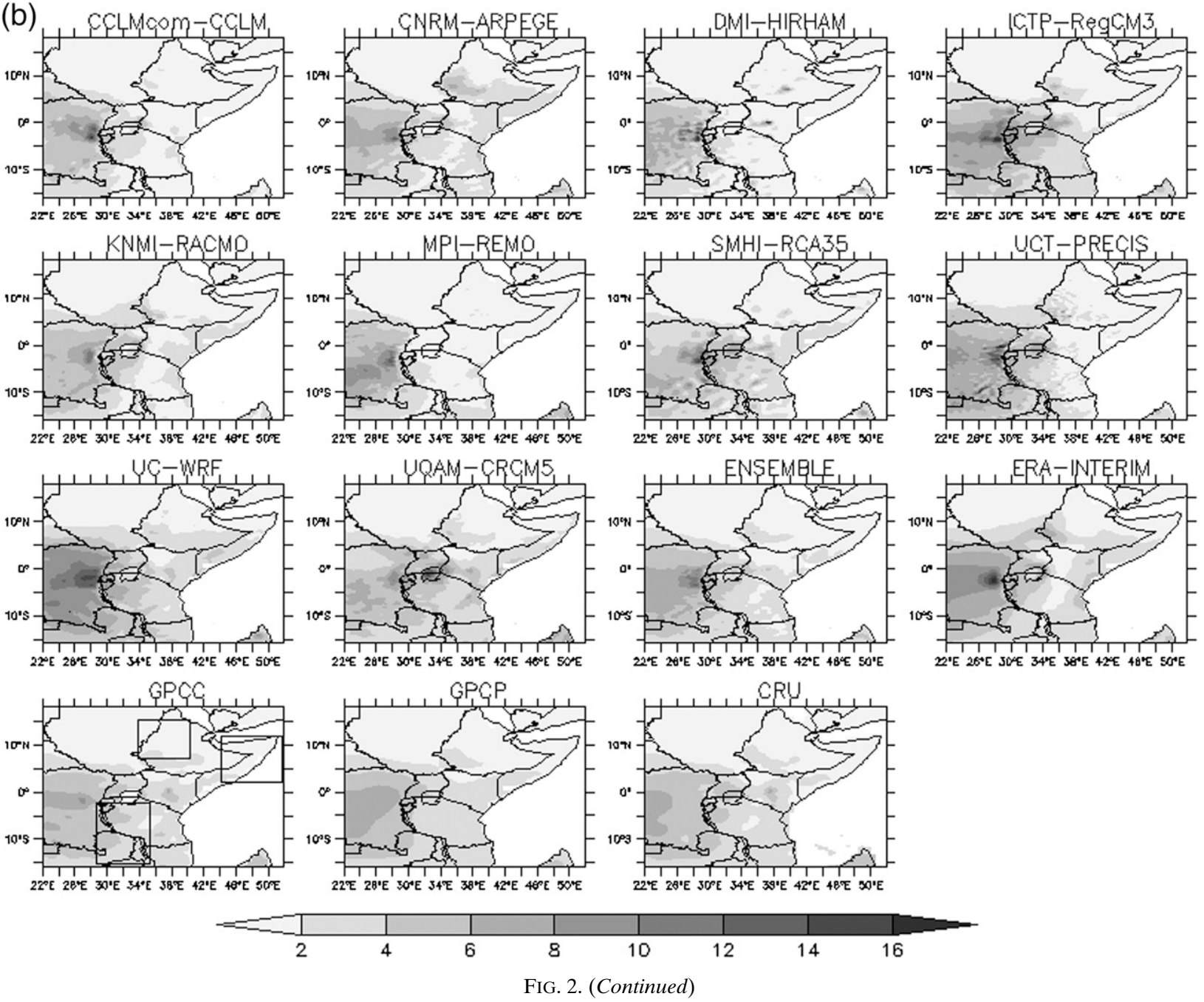

The centered RMS difference between the fields $E^{\prime}$ is given by Eq. (3):

$$
\begin{aligned}
E^{\prime} & =\sqrt{\frac{1}{N} \sum_{n=1}^{N}\left[\left(f_{n}-\bar{f}\right)-\left(r_{n}-\bar{r}\right)\right]^{2},} \\
\sigma_{f}^{2} & =\frac{1}{N} \sum_{n=1}^{N}\left(f_{n}-\bar{f}\right)^{2}, \\
\sigma_{r}^{2} & =\frac{1}{N} \sum_{n=1}^{N}\left(r_{n}-\bar{r}\right)^{2} .
\end{aligned}
$$

The second assessment of the ability of the RCMs is to capture the interannual rainfall variability and teleconnection signals. To assess the ability of the models in simulating the year-to-year variability of rainfall, time series of spatially averaged seasonal rainfall anomaly for JJAS over NEA and OND over EEA and SEA are analyzed.
Composite analysis is used to assess the RCMs' ability to reproduce rainfall anomalies associated with largescale features such as ENSO and IOD. We use the Ummenhofer et al. (2009) classification and develop composites of strong ENSO, IOD, and co-occurring events. These events are classified on the basis of their sea surface temperature (SST) indices. The condition for defining an El Niño or La Niña year is when the SST anomaly over Niño-3 region $\left(5^{\circ} \mathrm{S}-5^{\circ} \mathrm{N}, 90^{\circ}-150^{\circ} \mathrm{W}\right)$ is more than $1^{\circ} \mathrm{C}$ or less than $-1^{\circ} \mathrm{C}$ for two or more consecutive months between and including June and February of the following year, respectively. A year is counted as being positive or negative IOD when the SST anomaly over the western Indian Ocean region $\left(10^{\circ} \mathrm{S}-10^{\circ} \mathrm{N}, 50^{\circ}-\right.$ $70^{\circ} \mathrm{E}$ ) is larger than $1^{\circ} \mathrm{C}$ or less than $-1^{\circ} \mathrm{C}$ for two or more consecutive months between and including June and December, respectively. Details of the method for classifying years can be found in Meyers et al. (2007) and Ummenhofer et al. (2009). Using Table 2, we composite 

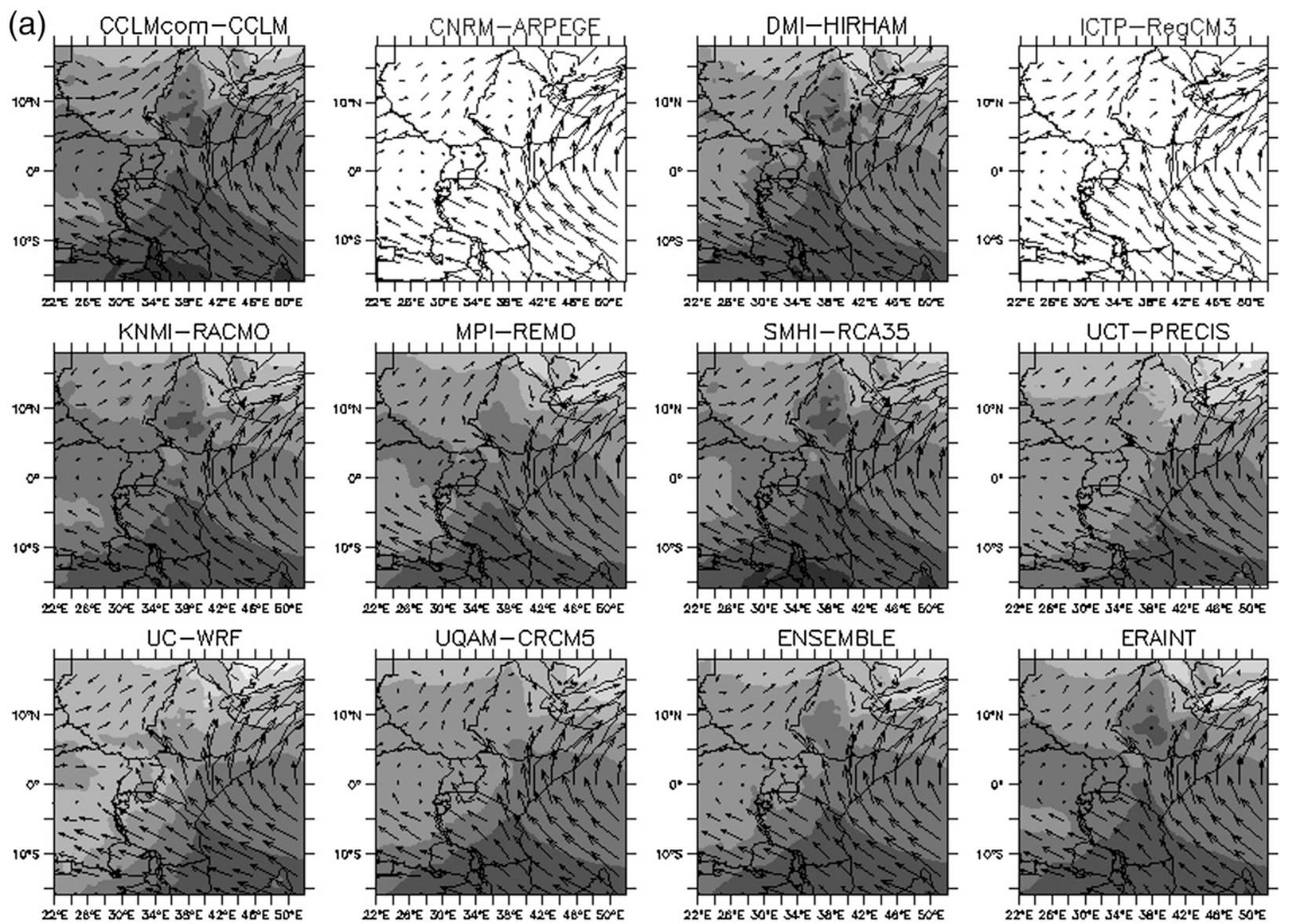

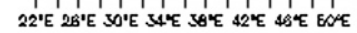

ENSEMBLE
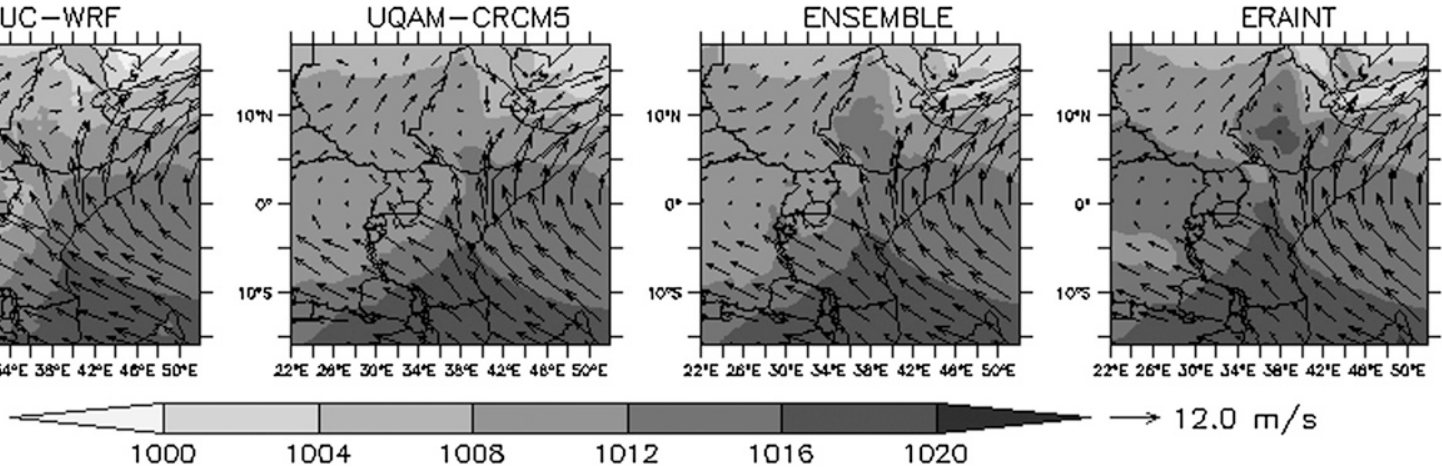

1004

1008

1012

1016

1020

FIG. 3. Climatology of mean sea level pressure (shaded, hPa) and $850-\mathrm{hPa}$ wind (vectors, $\mathrm{m} \mathrm{s}^{-1}$ ) during (a) JJAS and (b) OND as simulated by (top, middle, and one-half of bottom row) the 10 CORDEX RCMs in comparison with (bottom row, last two panels) ensemble and ERA-Interim. Mean sea level data were not available for ARPEGE and RegCM3.

years of positive-negative IOD, El Niño-La Niña, and co-occurrence events. ENSO and IOD events are analyzed separately to assess the role of each event in modulating rainfall variability over the region. The composites of El Niño, La Niña, positive IOD, negative IOD, and co-occurrence events are formed for the JJAS and OND seasons within the study period for observations and RCMs. The method is based on the difference between average of the seasonal rainfall of the event years and the climatology for the same season.

\section{Results and discussion}

\section{a. Seasonal averages}

\section{1) RAinfall CLimAtology}

Figures $2 \mathrm{a}$ and $2 \mathrm{~b}$ show the mean seasonal rainfall for JJAS and OND (averaged for 1990-2006) from the 10
CORDEX RCMs, the ERA-Interim reanalysis, and the ensemble mean of the RCMs in comparison with the observed datasets. All RCMs show rainfall band over land concentrated in the northern sector of the region, which is associated with the northward movement of ITCZ (Fig. 2a). Spatially, all the models capture the rainfall maximum over northern East Africa; however, most of the RCMs and ERA-Interim oversimulate rainfall over the Ethiopian highlands, while the ensemble mean has relatively good agreement with our reference dataset GPCC. During this period, most regions below the equator are dry and this is well captured by the RCMs.

During OND (Fig. 2b), the RCMs indicate that the rainfall band is concentrated over the equator and south of equator where the ITCZ is located at this time of the year. The RCMs reproduce most of the spatial structure of OND rainfall, although of higher intensity in the Congo airmass areas. 

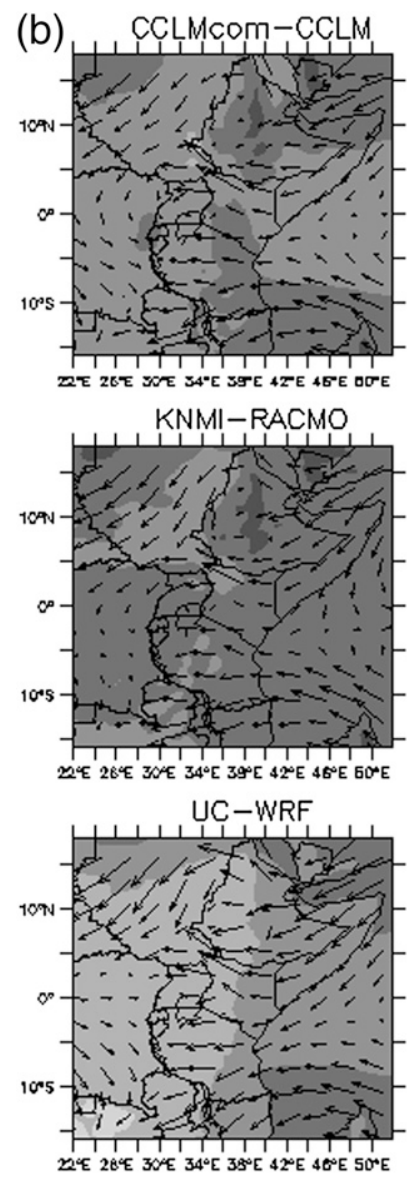

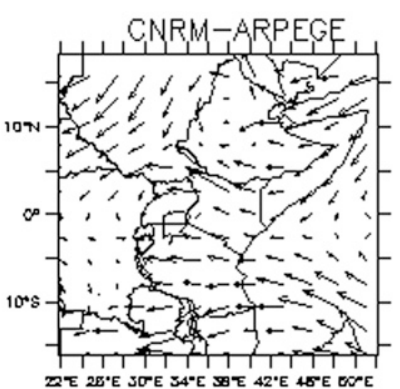

MPI-REMO

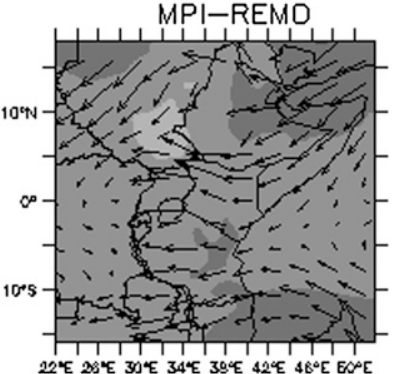

UQAM - CRCM5

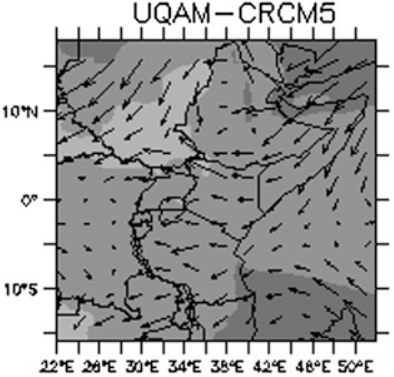

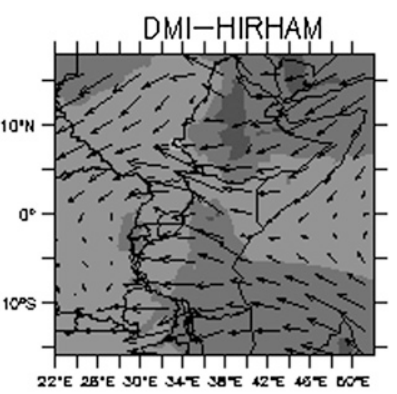

SMHI-RCA35

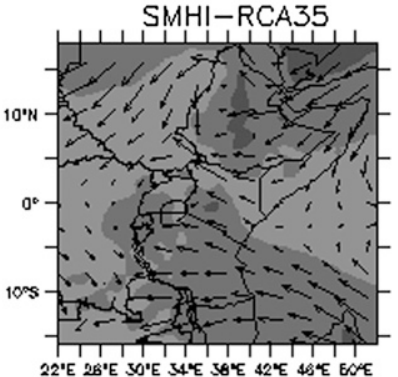

ENSEMBLE

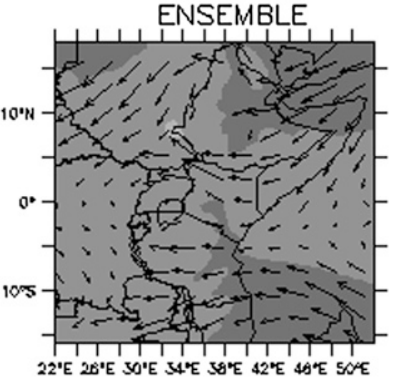

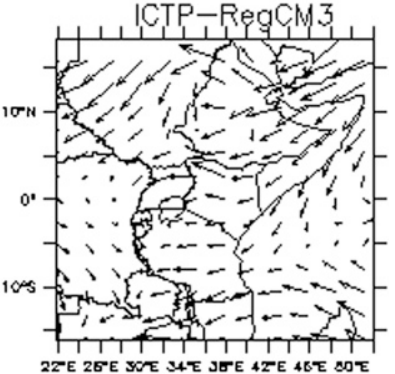

UCT-PRECIS

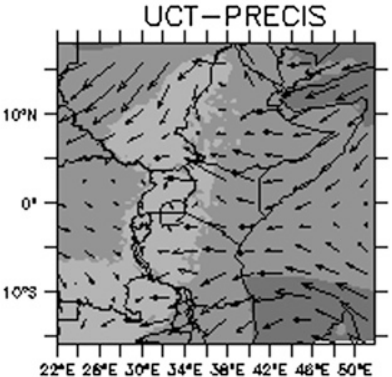

ERAINT

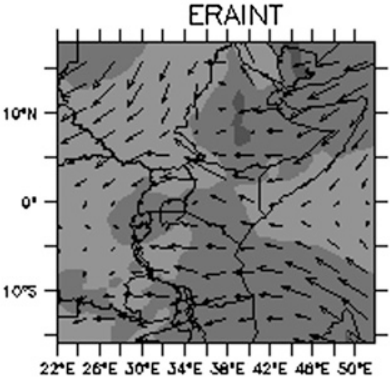

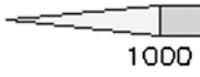

1020

FIG. 3. (Continued)

Thus, RCMs capture fairly well the rainfall seasonality, although they overestimate rainfall in some areas, especially over the Ethiopian highlands and Congo Basin during JJAS and OND, respectively.

\section{2) MEAN SEA LEVEL PRESSURE AND WIND FLOW PATTERN CLIMATOLOGY}

Figures $3 a$ and $3 b$ show the climatological pattern of mean sea level pressure and $850-\mathrm{hPa}$ wind for JJAS and OND from the 10 CORDEX RCMs and the ensemble mean in comparison with ERA-Interim reanalysis (note that sea level pressure is not available for the CNRMARPEGE and ICTP-RegCM3).

During JJAS the northern part of eastern Africa covering most of the Ethiopian highlands is dominated by a meridional ridge of weak high pressure, whereas the southern and south eastern part of the region is dominated by ridge of strong high pressure associated with the extended part of Mascarene high. The spatial extent and intensity of this pressure pattern is well represented by each RCM in comparison with ERA-Interim reanalysis. The intensity of strong westerly winds originate from Atlantic Ocean passes over Sudan, and the East African low-level jet (Somali jet) diverging out of the Mascarene high passes over the coast of eastern Africa are well simulated. These two features are the main source of moisture for the northern part of Ethiopia during JJAS (Segele et al. 2009b; Diro et al. 2011). The weak easterly winds over the Democratic Republic of Congo, Zambia, and Tanzania regions are also well represented. Furthermore, the models capture the role of the Ethiopian and East African highlands that blocks and recurves the circulation around the mountains.

During OND, much of the East African region is dominated by weak high pressure, except the central part of Ethiopia, and this is well represented by each RCM in agreement with ERA-Interim. Furthermore, the four airstreams influencing the regional rainfall patterns are well simulated (Fig. 3b). Two of the airstreams are in association with the Indian Ocean, the southeasterly and 
northeasterly components. These airstreams become easterly and converge along the equator. The northerly component climatologically influences Somalia and southern Ethiopia, while the southerly component influences Kenya and Tanzania (Nicholson 1996; Mpeta 2002). The third airstream is associated with the tropical Congo rain forest. This flow is much weaker with a westerly component. This airstream climatologically influences western portion of equatorial eastern Africa, in particular Uganda, Rwanda, and Burundi. The final airstream is associated with dry Saharan air seen over much of Sudan, thus explaining the smaller portions of rainfall received over this area during OND.

\section{b. Model bias}

Spatial plots of model bias from the reference field GPCC over the entire domain are analyzed (not shown). However, it is difficult to draw conclusions about the model bias over the entire domain as each model shows a wide variety of bias patterns in different parts of the domain. Therefore, a paired $t$ test for difference between mean values of RCMs and observed GPCC for each subregion at the 0.05 significance level is applied. The null hypothesis is that there is no difference between the two means (i.e., the means are equal). The alternative hypothesis is that there is a difference between the two means (the means are different). In fact, our assumption is that the rainfall data follow a normal distribution. Statistically significant biases that pass a Student's $t$ test at the 0.05 level are shown in bold (Table 3).

\section{1) JJAS}

During JJAS over NEA, all RCMs and observational datasets (GPCP and CRU) show statistically difference values at 0.05 level (Table 3 ). All RCMs show wet bias, except REMO and CCLM, which show dry bias.

\section{2) OND}

The paired $t$ test for difference between mean values of RCMs and GPCC shows that all the 10 RCMs indicate wet bias in reproducing the OND rainfall over EEA, whereas CCLM, ARPEGE, HIRHAM, RACMO, and REMO show dry bias in reproducing OND rainfall over SEA (Table 3). All the biases are statistically significant at the 0.05 level. The ensemble mean, ERAInterim, and the two observed datasets (GPCP and CRU) have a small bias over SEA that is not statically significant.

Using the ensemble mean as a reference (Table 4), CCLM, ARPEGE, RACMO, REMO, and CRCM5 show statically significant dry bias, whereas WRF and RegCM3 show wet bias over NEA during JJAS. Over EEA during OND, CCLM, HIRHAM, RegCM3, and PRECIS show wet bias, whereas REMO, WRF, and CRCM5 show dry bias that is statistically significant at the 0.05 level. All RCMs show statistically significant bias over SEA using the ensemble mean as a reference field.

\section{c. Spatial correlation}

The consistency of the models in representing the spatial distribution of rainfall with time for each subregion is evaluated using spatial correlation. Figure 4 depicts the magnitude and variability of spatial correlations of the RCMs, ensemble mean, ERA-Interim, GPCP, and CRU with GPCC over time during JJAS over NEA and during OND over EEA and SEA.

The results for NEA show that CRCM5, RACMO, RegCM3, RCA, and the ensemble mean have high and consistent correlation with the GPCC data during JJAS while CCLM, HIRHAM, REMO, PRECIS, ARPEGE, and WRF are relatively weakly correlated (between 0.7 and 0.4 ) with the GPCC data. The HIRHAM model has the lowest correlation with GPCC in this region and it is noteworthy that the CCLM model poorly represented the spatial pattern of rainfall during the $1998 \mathrm{La}$ Niña event. The two observed datasets (GPCP and CRU) and ERA-Interim have relatively higher and more consistent correlation with GPCC than the individual models.

Over EEA, most of the models are inconsistent in representing spatial rainfall distribution except RACMO, RegCM3, and the ensemble mean, which have good and consistent rainfall representation. The CCLM, HIRHAM, and REMO models have relatively poor correlation in terms of magnitude and consistency. Again, poor representation is displayed by CCLM during the 1997 cooccurrence of the strong El Niño and positive IOD event, and in REMO during the 1994 IOD event. This shows the shortcoming of the two models in capturing the response from ENSO and IOD events. Over this region, the CRU dataset shows inconsistency in representing the spatial distribution of rainfall.

Over SEA, all RCMs and ERA-Interim had nearly same level of consistency in reproducing spatial patterns of rainfall during OND. Although the two observed datasets have better agreement with GPCC than individual models, inconsistency in spatial distribution is observed for CRU dataset.

\section{d. Annual cycles}

Figure 5 illustrates the performance of the CORDEX RCMs in simulating annual rainfall cycle for the three subregions. In NEA and SEA, all of the RCMs capture the shape of the rainfall seasonality well. However, in EEA most of the models poorly reproduce the OND rainfall peak. The GPCP observed data wrongly 
TABLE 3. Difference between seasonal mean rainfall between each RCM and GPCC during 1) JJAS in subregion NEA and 2) OND in subregions EEA and SEA. Bold values are significant at the 0.05 level.

\begin{tabular}{lccc}
\hline \hline Model comparison & JJAS (NEA) & OND (EEA) & OND (SEA) \\
\hline CCLM-GPCC & $-\mathbf{0 . 3 6}$ & $\mathbf{0 . 6 5}$ & $-\mathbf{1 . 3}$ \\
ARPEGE-GPCC & $\mathbf{0 . 8 4}$ & $\mathbf{1 . 2 3}$ & $-\mathbf{1 . 0 2}$ \\
HIRHAM-GPCC & $\mathbf{0 . 9 9}$ & $\mathbf{0 . 5 3}$ & $-\mathbf{1 . 4 9}$ \\
RegCM3-GPCC & $\mathbf{2 . 2 8}$ & $\mathbf{0 . 4 4}$ & $\mathbf{1 . 2 9}$ \\
RACMO-GPCC & $\mathbf{0 . 8 3}$ & $\mathbf{1 . 1 5}$ & $-\mathbf{0 . 6 9}$ \\
REMO-GPCC & $-\mathbf{0 . 7 6}$ & $\mathbf{1 . 3 7}$ & $-\mathbf{1 . 2 7}$ \\
RCA-GPCC & $\mathbf{0 . 9 4}$ & $\mathbf{1 . 2 5}$ & $\mathbf{0 . 5}$ \\
PRECIS-GPCC & $\mathbf{0 . 9 8}$ & $\mathbf{0 . 7 1}$ & $\mathbf{0 . 9 6}$ \\
WRF-GPCC & $\mathbf{3 . 0 1}$ & $\mathbf{1 . 6 8}$ & $\mathbf{1 . 6 2}$ \\
CRCM5-GPCC & $\mathbf{0 . 8 4}$ & $\mathbf{1 . 5 1}$ & $\mathbf{0 . 6 2}$ \\
Ensemble-GPCC & $\mathbf{0 . 9 6}$ & $\mathbf{1 . 0 5}$ & -0.08 \\
ERA-Interim-GPCC & $\mathbf{1 . 8}$ & $\mathbf{1 . 0 2}$ & -0.07 \\
GPCP-GPCC & $-\mathbf{0 . 2 1}$ & $\mathbf{0 . 4}$ & -0.02 \\
CRU-GPCC & $-\mathbf{0 . 3}$ & -0.13 & -0.18 \\
\hline
\end{tabular}

represent the rainfall peak both over NEA and EEA subregions, while GPCC and CRU indicate nearly the same pattern of seasonality in all subregions. The wrong representation of seasonality in GPCP might be due to its coarse resolution. In all the regions, the ensemble mean have been found to have relatively good performance as compared to individual models. The WRF is found to be significantly overestimating rainfall over all three subregions.

In general, there is fairly good agreement between annual rainfall cycle simulated by CORDEX RCMs and the reference field (GPCC). The most notable shortcoming in most RCMs is overestimation of the monthly mean.

\section{e. Taylor diagram}

The models' ability to simulate both the pattern and amplitude of the observed interannual variation is provided by a Taylor diagram. Figure 6 summarizes the pattern correlation $(r)$, root-mean-square difference, and the amplitude of variation of seasonal mean rainfall of each RCM, ensemble mean, and ERA-Interim with respect to the reference field (GPCC) for each of the three subregions. To provide an overview of observational uncertainty, GPCP and CRU are also compared to GPCC and plotted in the same diagram. All the statistics are computed for 1990-2006.

Over NEA during JJAS, most of the model show relatively low correlation coefficient compared to the other subregions (i.e., $r<0.8$ ). RACMO, PRECIS, REMO, and CRCM5 have relatively high pattern of correlation and low root-mean-square difference and has a variation close to the reference field (GPCC). The ensemble mean has better agreement with GPCC than
TABLE 4. Difference between seasonal mean rainfall between each RCM and the ensemble mean during JJAS in subregion NEA and OND in subregions EEA and SEA. Bold values are significant at the 0.05 level.

\begin{tabular}{lccc}
\hline \hline RCM comparison & JJAS (NEA) & OND (EEA) & OND (SEA) \\
\hline CCLM-ensemble & $-\mathbf{1 . 6 3}$ & $-\mathbf{0 . 4}$ & $-\mathbf{1 . 2 2}$ \\
ARPEGE-ensemble & $-\mathbf{0 . 4 3}$ & 0.18 & $-\mathbf{0 . 9 4}$ \\
HIRHAM-ensemble & -0.28 & $-\mathbf{0 . 5 2}$ & $-\mathbf{1 . 4 1}$ \\
RegCM3-ensemble & $\mathbf{1 . 0 1}$ & $-\mathbf{0 . 6 1}$ & $\mathbf{1 . 3 7}$ \\
RACMO-ensemble & $-\mathbf{0 . 4 4}$ & 0.09 & $-\mathbf{0 . 6 1}$ \\
REMO-ensemble & $-\mathbf{2 . 0 3}$ & $\mathbf{0 . 3 2}$ & $-\mathbf{1 . 1 9}$ \\
RCA-ensemble & -0.33 & 0.2 & $\mathbf{0 . 5 7}$ \\
PRECIS-ensemble & -0.28 & $-\mathbf{0 . 3 4}$ & $\mathbf{1 . 0 3}$ \\
WRF-ensemble & $\mathbf{1 . 7 3}$ & $\mathbf{0 . 6 2}$ & $\mathbf{1 . 7}$ \\
CRCM5-ensemble & $-\mathbf{0 . 4 3}$ & $\mathbf{0 . 4 6}$ & $\mathbf{0 . 7}$ \\
\hline
\end{tabular}

individual models (i.e., $r=0.84$ ) or ERA-Interimderived data. ERA-Interim shows extremely high variation compared to the GPCC. Regarding the observed datasets, the GPCP agrees best with GPCC. CRU and multimodel ensemble have nearly the same level of correlation coefficient, but the ensemble mean shows lower variation than GPCC, while CRU shows higher variation than GPCC.

Over EEA during OND, most of the models underestimate the magnitude of interannual variation relative to GPCC, while three models (WRF, CRCM5, and RCA) overestimate the variation. CCLM, RACMO, CRCM5, and the ensemble mean have relatively higher correlation and low RMS errors than other RCMs as well as the ERA-Interim reanalysis. It has been also noticed that there is a large spread among observational datasets. GPCP has a standard deviation higher than GPCC, while CRU shows a variation much lower than GPCC. But GPCP has relatively higher correlation and lower rootmean-square difference than CRU.

Over SEA, all RCMs show a variation lower than the observed except the WRF, which shows larger than the observed. ARPEGE, ERA-Interim, and the ensemble mean have a relatively higher pattern of correlation (i.e., $r>0.8$ ) and lower root-mean-square difference than the rest of the RCMs. The GPCP agrees best with GPCC.

Generally, some regional climate models have outperformed the derived ERA-Interim (in relation to the observed GPCC) and others have not; however, the multimodel ensemble is found generally closer to the GPCC than individual models as well as the derived ERA-Interim. The WRF Model has showed a variation higher than the observed in all subregions. Even though there is large uncertainty between observational datasets, GPCP has better agreement with GPCC than CRU in all subregions. Particularly over subregion SEA, GPCP has a correlation coefficient of above 0.99 and has a similar interannual variation with GPCC. 

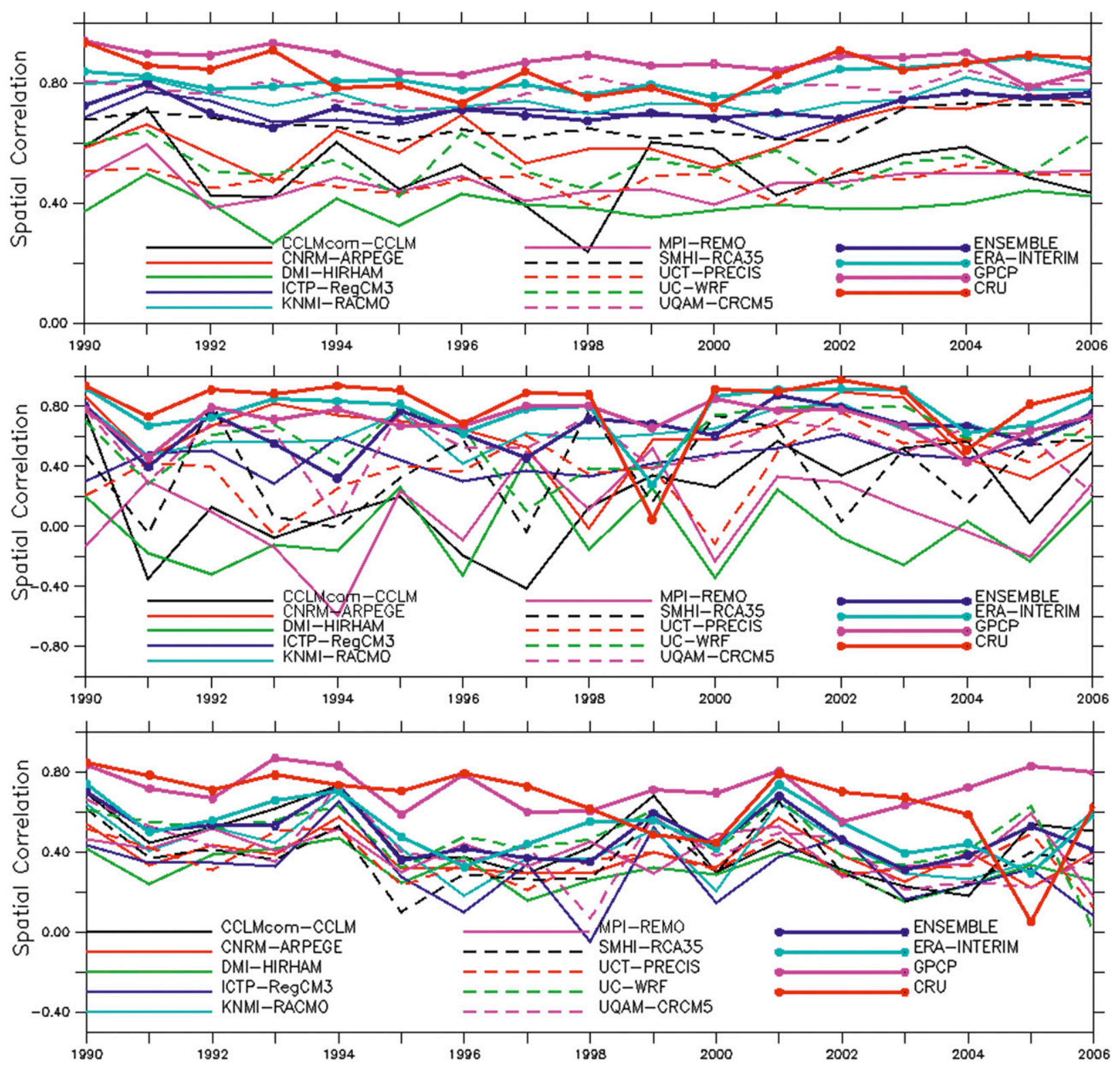

FIG. 4. Spatial correlations between GPCC and the CORDEX RCMs (top) over NEA during JJAS, (middle) over EEA during OND, and (bottom) over SEA during OND.

\section{f. Interannual rainfall variability}

The temporal pattern of rainfall over eastern Africa has a strong interannual rainfall variability associated with extreme events such as floods and droughts. Previous studies have shown that the interannual rainfall variability is strongly associated with perturbations in the global SSTs, especially over the equatorial Pacific and Indian Ocean basins (Ogallo 1988; Nicholson and Kim 1997; Indeje et al. 2000; Saji et al. 1999; Black et al. 2003; Clark et al. 2003 Nyakwada 2009; Omondi et al. 2013). The influence of global SST on eastern Africa rainfall depends on the season and the region. Generally, during JJAS El Niño conditions produce deficit rainfall and La Niña conditions produce excess rainfall over the northern parts of East Africa, whereas during OND the equatorial and southern parts of East Africa get below average rainfall during La Niña and above average during El Niño.

Figure 7 shows time series analysis of area averaged seasonal rainfall anomalies of the RCMs, the ensemble, ERA-Interim, and observed (GPCP and CRU) rainfall over the three subregions in comparison to GPCC. During JJAS, the observed rainfall variability is well 

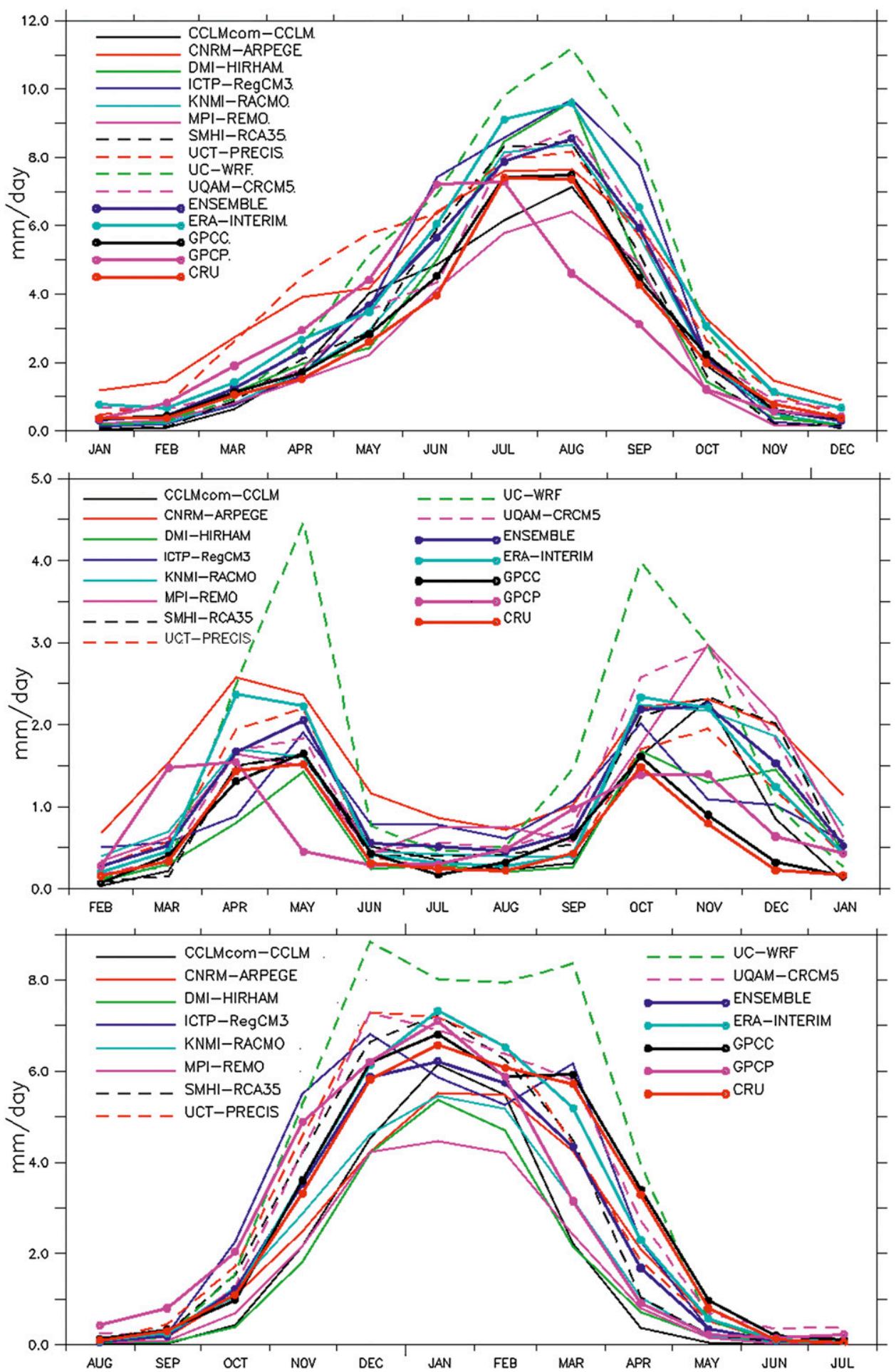

FIG. 5. Mean annual cycle of rainfall over (top) NEA, (middle) EEA, and (bottom) SEA (mm day ${ }^{-1}$ ) from the $10 \mathrm{RCMs}$, ensemble, ERA-Interim reanalysis, and observations.

reproduced by most RCMs over NEA except for ARPEGE, which showed some deviation. ERA-Interim poorly represented the year-to-year variability of rainfall, which also was shown in Fig. 6 over NEA. Most RCMs capture the extreme years such as El Niño years of 1991, 1997, and 2004 with minimum rainfall whereas during La Niña years $(1998,1999)$ rainfall is above average. In EEA, almost all the RCMs realistically simulate the 

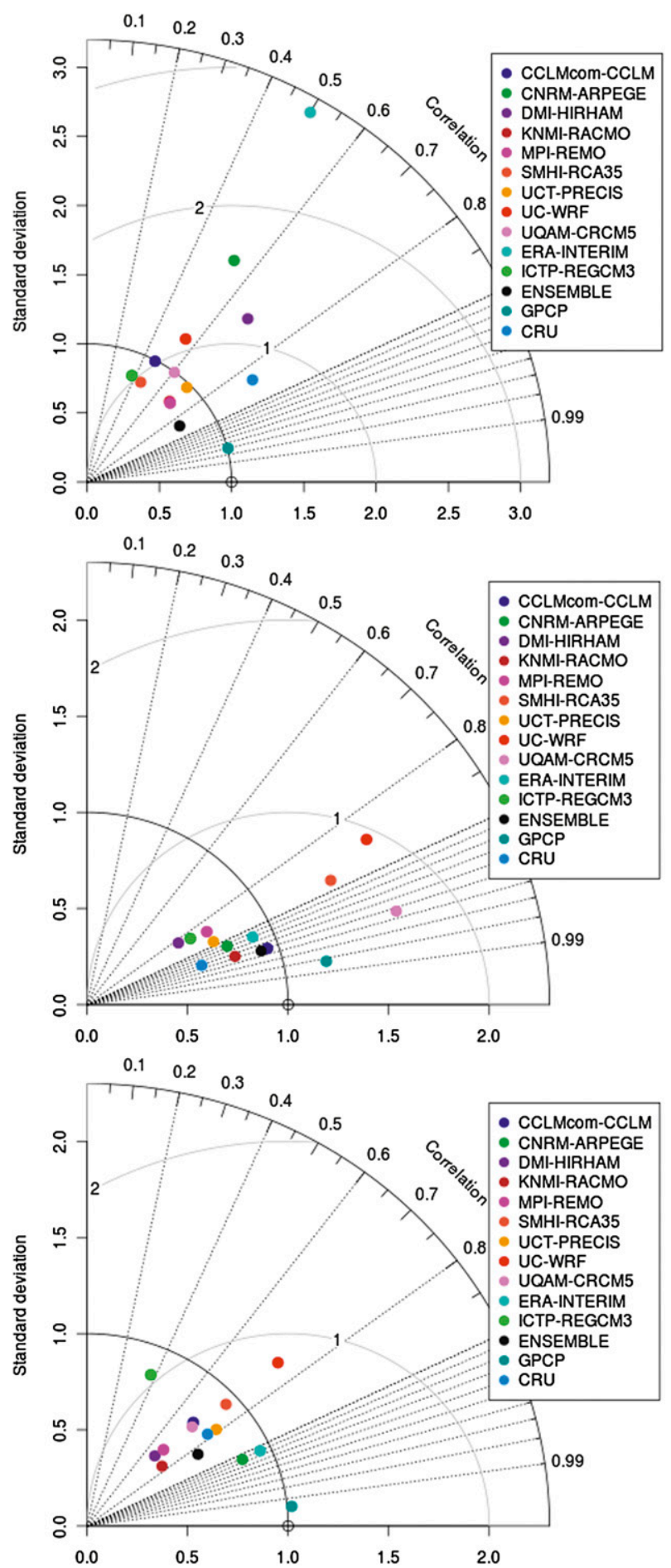

FIG. 6. Taylor diagram displaying normalized statistical comparison of seasonal mean rainfall of the 10 RCMs and ERAInterim reanalysis with observation over (top) NEA during JJAS, (middle) EEA during OND, and (bottom) SEA during OND. interannual rainfall variability, notably the 1997 high rainfall event that was associated with strong El Niño in phase with positive IOD. CRU shows low year-to-year variability of rainfall (also shown in Fig. 6 over EEA with low standard deviation value). In SEA, the RegCM3 and WRF do not capture well the interannual rainfall variability. Although the ERA-Interim reanalysis and ARPEGE model did not capture the rainfall variability in the NEA, in the latter two regions they best represented the observed GPCC rainfall during the El Niño of 1997.

\section{g. Teleconnection}

The teleconnection associated with East African rainfall is quite complex as several forcings control the rainfall variability for various seasons and regions. In this section, we assess the ability of CORDEX RCMs in capturing teleconnection signals using composite analysis. The composite of each ENSO and IOD event is formed separately to examine how well the models are able to translate the teleconnection signal from the boundary forcing into the interior of the domain and also to understand the relative influence of the events on the rainfall variability over the region.

Figure 8 shows the JJAS rainfall anomaly simulated by CORDEX RCMs and ERA-Interim reanalysis in comparison to the observation when pure La Niña events are composited (refer to Table 2). Most of the RCMs and ERA-Interim show a positive rainfall anomaly over large parts of the Ethiopian highlands and South Sudan in agreement with observation. This indicates that during La Niña events there is an increase of rainfall over the northern parts of eastern Africa during JJAS. This finding is in agreement with previous studies (e.g., Diro et al. 2011; Gissila et al. 2004; Korecha and Barnston 2007; Segele et al. 2009b, and others) that associated the positive rainfall anomalies over the Ethiopian highland during JJAS with La Niña, and the negative rainfall anomalies with El Niño.

It should be noted that in our analysis period there is no pure El Niño event to investigate whether the models can translate the signal into the domain. However, cooccurrence events of El Niño and positive IOD are studied. Figure 9 represents rainfall anomaly for the cooccurrence of El Niño and positive IOD events during JJAS. Both simulated and observed results show negative rainfall anomalies during JJAS over large parts of the Ethiopian highlands and South Sudan. Most of the RCMs simulate the negative rainfall anomaly quite well, which is also a mirror image of La Niña impacts. However, only two models (RCA and WRF) capture the drier anomaly over the northern and eastern parts of the Democratic Republic of Congo, whereas most of the 

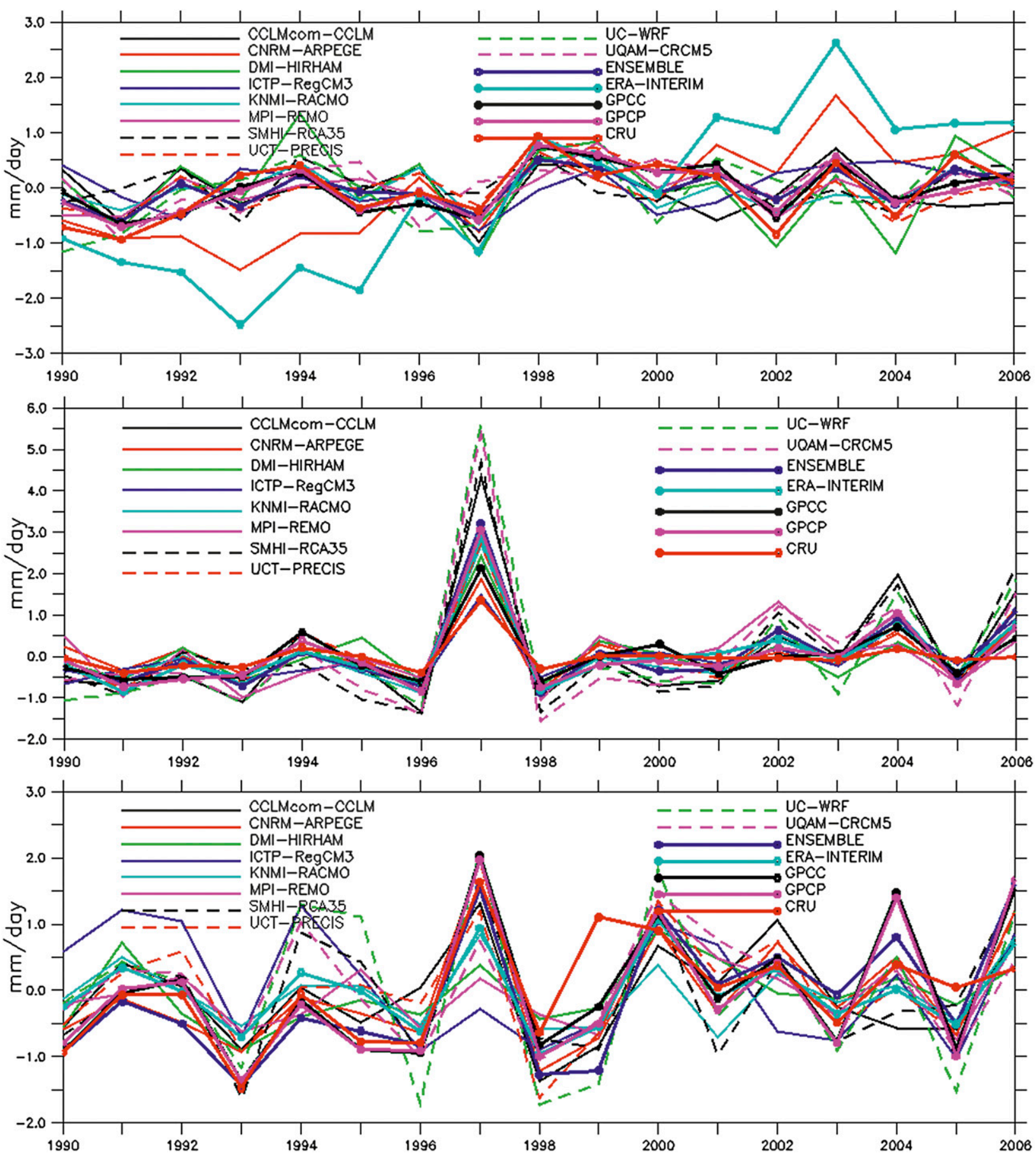

FIG. 7. Time series of CORDEX RCMs, ensemble, and observed rainfall anomalies ( $\mathrm{mm} \mathrm{day}^{-1}$ ) over (top) NEA during JJAS, (middle) EEA during OND, and (bottom) SEA during OND.

other models show wetter anomalies and the ensemble mean of this region shows no anomaly.

The rainfall anomalies during pure La Niña and cooccurrence of El Niño with positive IOD events for OND are shown in Figs. 10 and 11. Most of the RCMs correctly simulate negative rainfall anomaly during OND in the equatorial and southeastern parts of the region when La Niña years are composited (Fig. 10). A similar but reverse response is observed in co-occurrence of $\mathrm{El}$ Niño with positive IOD composites (Fig. 11), which is associated with increased rainfall during OND. Similar findings have been reported in a number of previous 

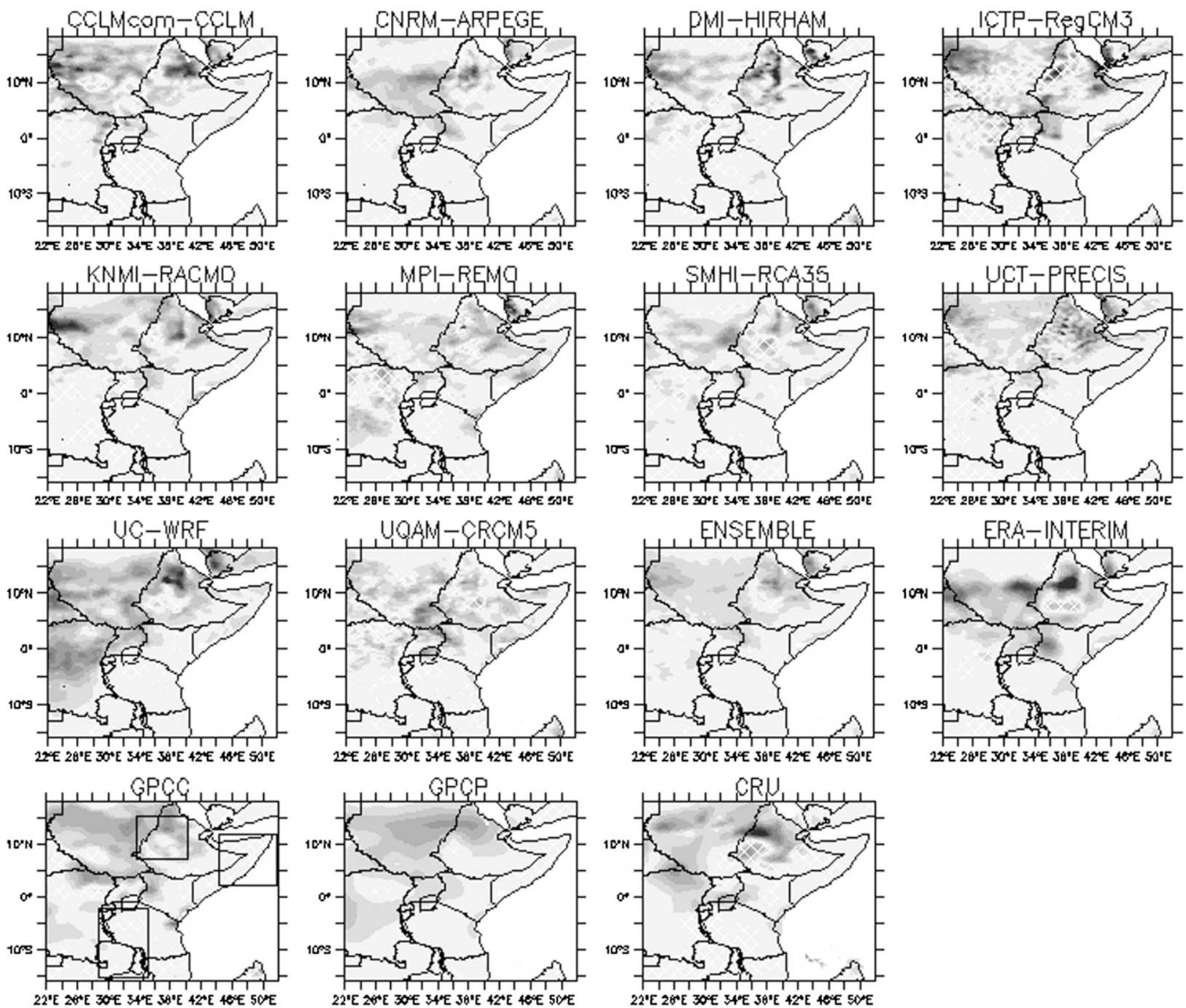

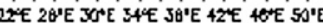

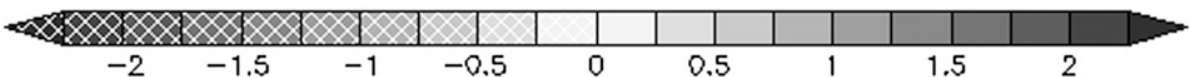

FIG. 8. As in Fig. 2a, but for JJAS rainfall anomaly $\left(\mathrm{mm}^{\mathrm{day}}{ }^{-1}\right)$ during pure La Niña conditions.

studies (e.g., Ropelewski and Halpert 1987; Ogallo 1988; Indeje et al. 2000; Nicholson and Kim 1997). The warm phase of ENSO (El Niño) is associated with excess rainfall and flooding, while the cold phase (La Niña) often coincides with extreme drought conditions during the short rain in much of equatorial East Africa (Ogallo 1988; Nicholson and Kim 1997).

To understand the effects of IOD over the region, the pure positive and negative IOD composites are plotted separately. The positive IOD composites for JJAS, positive IOD composites for OND, and negative IOD composites for JJAS and OND have been analyzed over the region (results not shown), and all of the results show weak and localized rainfall anomalies compared to the ENSO composites.
In general, results from the composite analysis have shown that most of the models capture the response of large-scale signals over eastern Africa during the anomalous events with respect to observations, where the ensemble mean outperforms the individual models. Both the RCMs and observed results show that ENSO has a strong association for rainfall over the region while the effect of IOD is weak and localized.

\section{Summary and conclusions}

In this study, the performance of 10 CORDEX RCMs was evaluated for their ability to capture and characterize rainfall patterns over East Africa as well as their ability to reproduce the response to large-scale global 

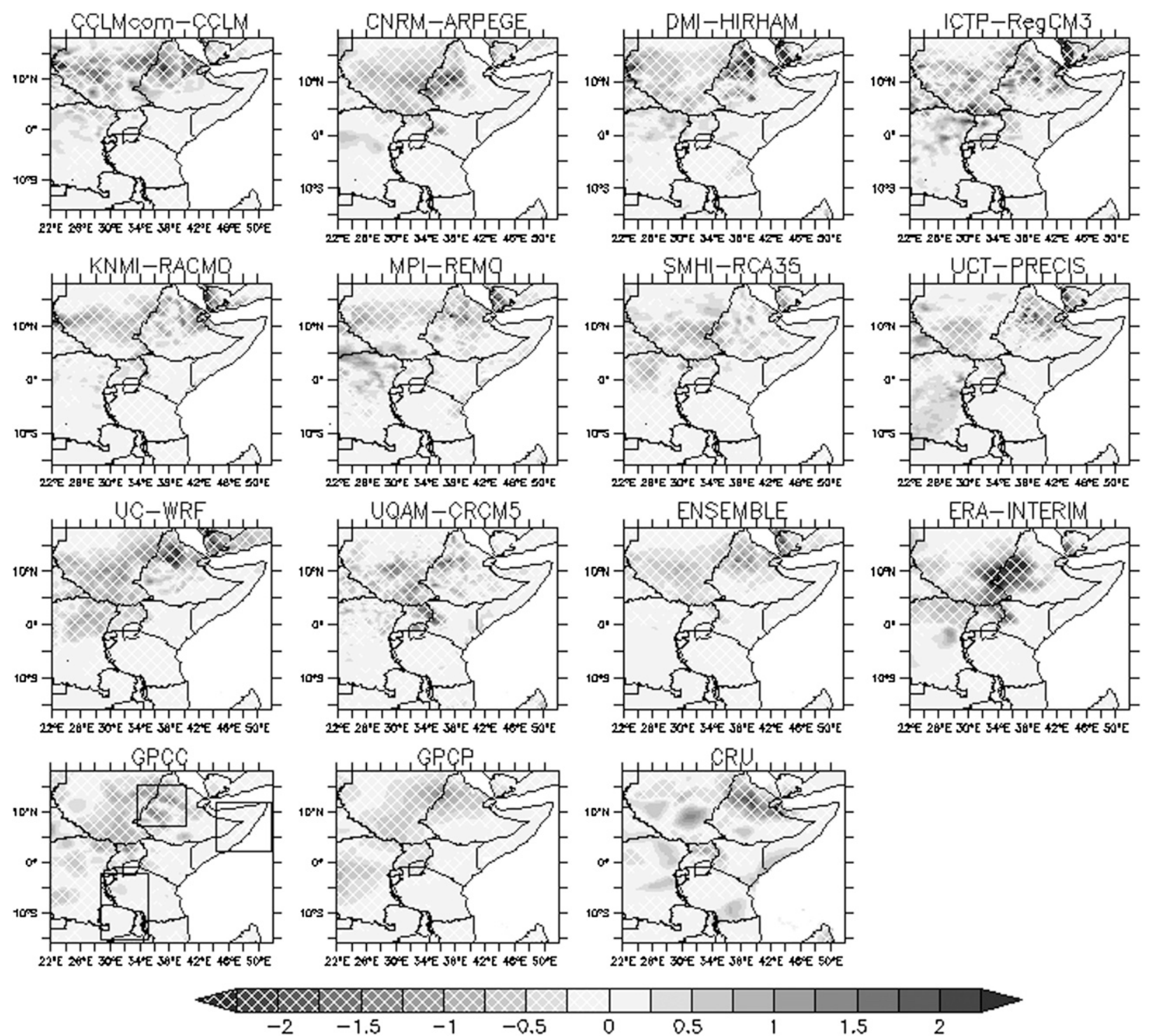

FIG. 9. As in Fig. 2a, but for JJAS rainfall anomaly $\left(\mathrm{mm} \mathrm{day}^{-1}\right)$ during the co-occurrence of El Niño and positive IOD.

signals during the period 1990-2008. In the northern sector of the region, JJAS is considered to be the long rainy season as the region receives the largest fraction of its total annual rainfall in these months. All RCMs realistically simulated the rainfall belt associated with the ITCZ during this season although most of the models show wet bias apart from REMO and CCLM, which showed dry bias. During OND, all RCMs captured well the ITCZ belt. It was noted that $10 \mathrm{RCMs}$ indicated wet bias over EEA while CCLM, ARPEGE, HIRHAM, RECMO, and REMO show dry bias in reproducing OND rainfall over SEA. CRCM5, RACMO, RegCM3, and RCA showed high spatial correlations together with consistency in reproducing spatial patterns of rainfall over time for JJAS in NEA and RACMO and RegCM3 during OND in EEA. The 10 RCMs had nearly same level of consistency in reproducing spatial patterns in SEA sector during OND. Overall, the $10 \mathrm{RCMs}$ considered in the present study represent the correct shape of the mean annual cycle of rainfall over both NEA and SEA, but with a small shift in capturing the correct peak of the dominant bimodal rainfall regimes in EEA. Generally, most of the models capture the regional rainfall anomaly associated with ENSO and IOD in agreement with the observations. Both model and observed results showed that ENSO has a strong association for rainfall over the region while the effect of IOD is weak and localized. Many studies have shown that downscaling 

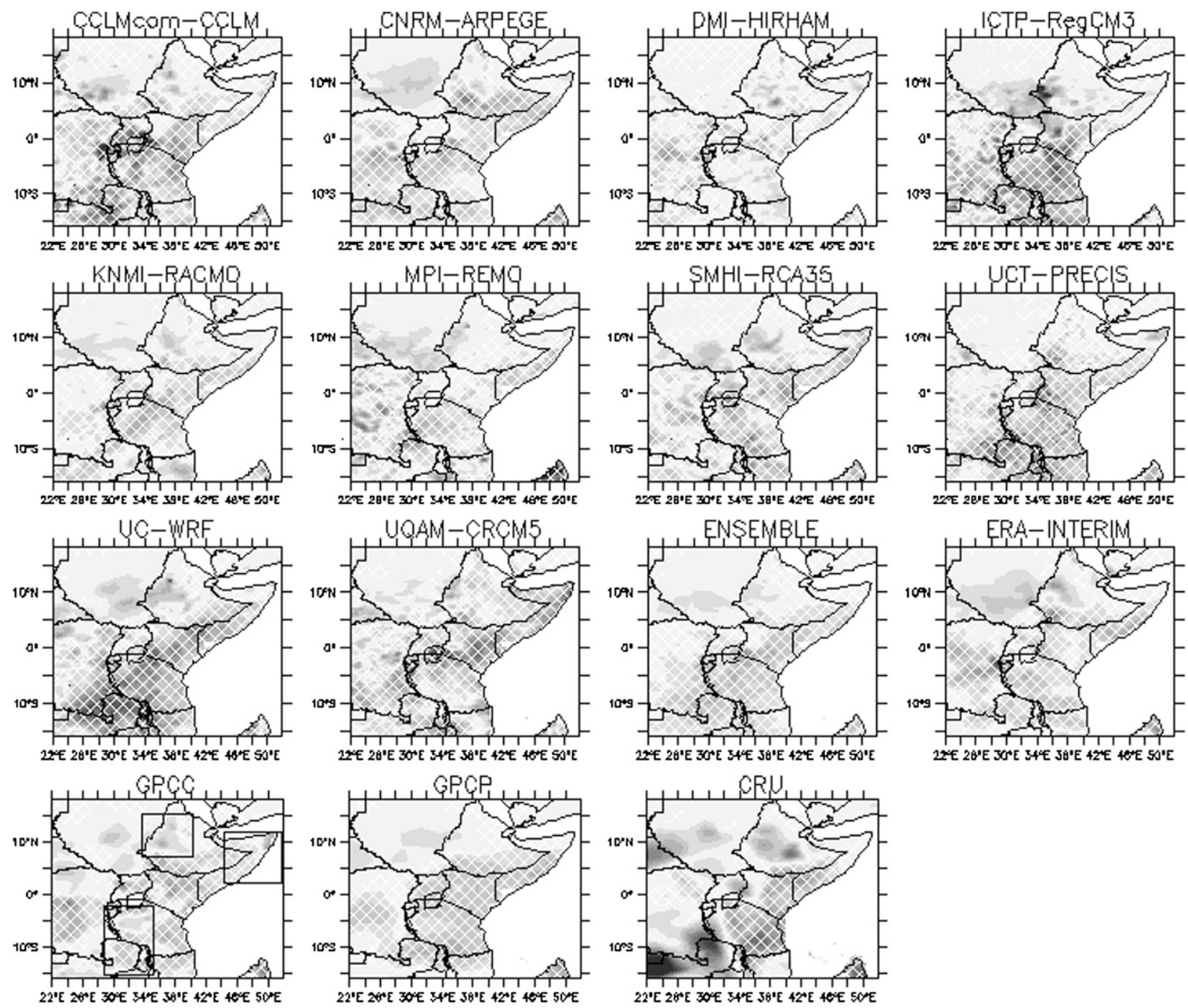

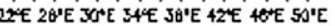

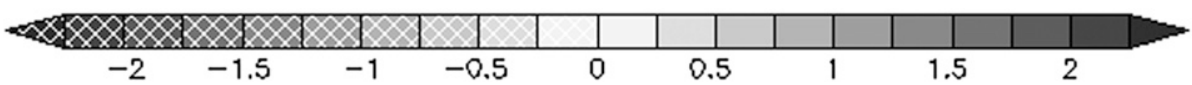

FIG. 10. As in Fig. 8, but for OND.

global models to the regional scale adds value to information at these finer scales (Giorgi and Marinucci 1996; Giorgi and Mearns 1999; Giorgi et al. 1993a,b; Sun et al. 1999a,b; Anyah and Semazzi 2006; Anyah et al. 2006). We have demonstrated that some regional climate models used in CORDEX-Africa have outperformed the ERA-Interim rainfall (in relation to the observed GPCC) and others have not; however, the ensemble mean of the RCM output is mostly closer to the GPCC data than the ERA-Interim. As the CORDEX RCMs are forced by ERA-Interim reanalysis, this would suggest that downscaling coarser model output improves rainfall representation at the regional scale.
In general, most of the RCMs overestimated rainfall in all the three subregions, WRF in particular. The multimodel ensemble mean outperforms the results of individual models, and even ERA-Interim, in most of the areas and time periods as assessed by different criteria. This is likely because of the cancellation of opposite signed biases across the models. Similar results have been shown by Paeth et al. (2011) and in the CORDEX context by Nikulin et al. (2012). At the level of individual models it is of concern that many models produce good results in one region and poor results in another over the same time period. This would suggest that some models may be getting correct results in particular regions for the wrong reasons. It is beyond the 

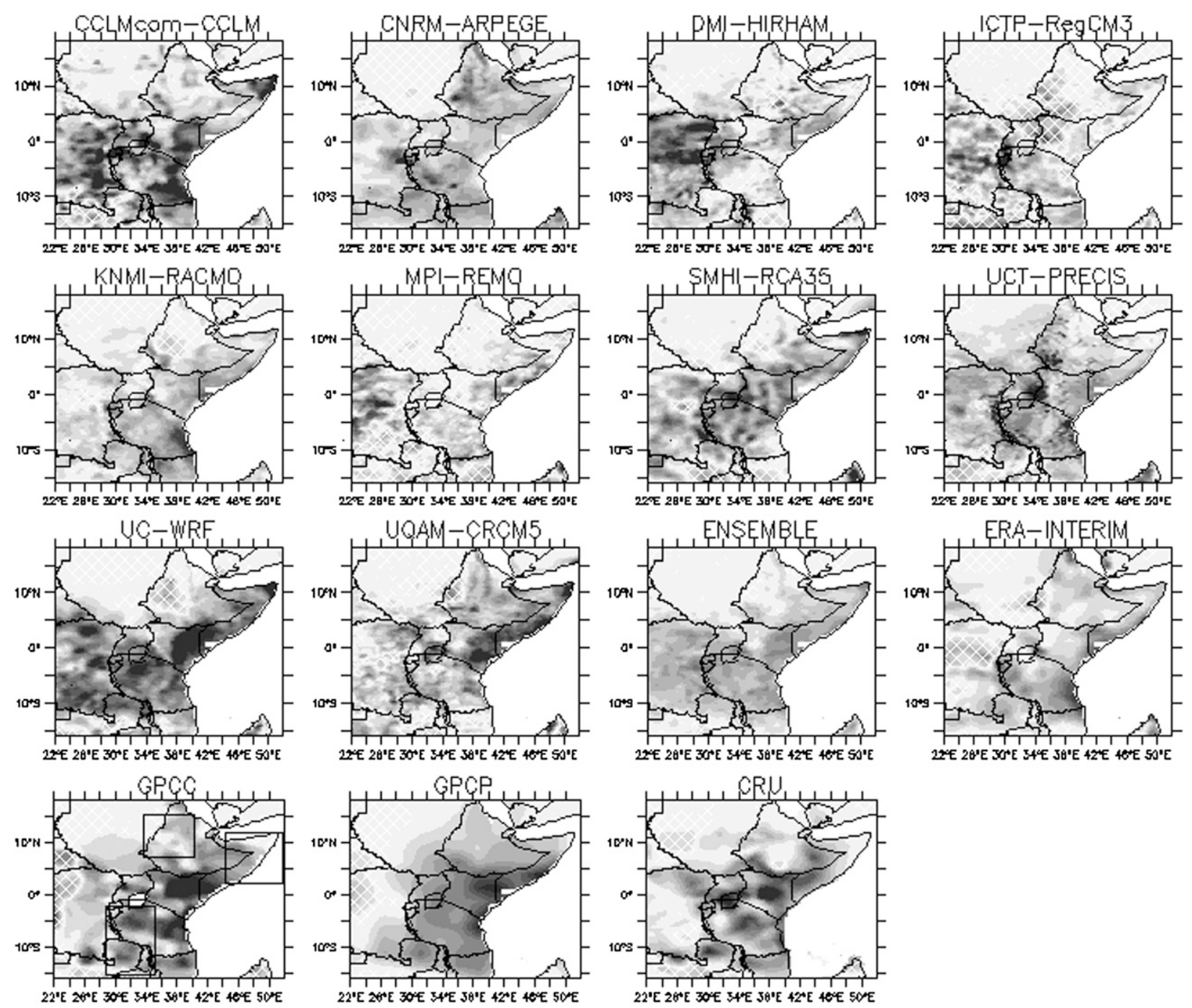

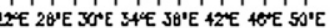

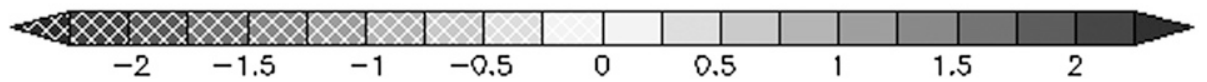

FIG. 11. As in Fig. 9, but for OND.

scope of this paper to investigate the individual models in depth but this is a major caveat in interpreting the results. Despite this, we have demonstrated that the multimodel ensemble mean simulates eastern Africa rainfall adequately and can therefore be used for the assessment of future climate projections for the region.

Acknowledgments. This research was supported by the Global Change System for Analysis, Research, and Training (START) in partnership with the University of Cape Town's Climate Systems Analysis Group, the World Climate Research Program, the Climate and Development Knowledge Network, the International Centre for Theoretical Physics, and the Swedish
Meteorological-Hydrological Institute. We would also like to thank the regional downscaling groups who provided the downscaled data used in this analysis (see Table 1). Special thanks to Grigory Nikulin at the Swedish Meteorological and Hydrological Institute whose efforts ensured these data were post-processed to common grids and formats so that they were directly comparable in CORDEX-Africa analyses. We also acknowledge Eastern Africa modeling groups and their respective institutions for their roles in this research.

H. S. Endris would like to thank the SOCOCA project in Department of Geoscience at University of Oslo (DoG/UiO) for the scholarship support for his study at University of Cape Town. 


\section{REFERENCES}

Alley, R. B., and Coauthors, 2007: Summary for policymakers. Climate Change 2007: The Physical Science Basis, S. Solomon et al., Eds., Cambridge University Press, 1-18.

Anyah, R. O., 2005: Modelling the variability of the climate system over Lake Victoria basin. Ph.D. thesis, Department of Marine, Earth and Atmospheric Sciences, North Carolina University, 288 pp.

— , and F. H. M. Semazzi, 2006: Climate variability over the Greater Horn of Africa based on NCAR AGCM ensemble. Theor. Appl. Climatol., 86, 39-62, doi:10.1007/s00704-005-0203-7. , and - 2007: Variability of East African rainfall based on multiyear RegCM3 simulations. Int. J. Climatol., 27, 357-371, doi:10.1002/joc.1401.

—, and W. Qiu, 2012: Characteristic 20th and 21st century rainfall and temperature patterns and changes over the Greater Horn of Africa. Int. J. Climatol., 32, 347-363, doi:10.1002/ joc. 2270 .

—, F. H. M. Semazzi, and L. Xie, 2006: Simulated physical mechanisms associated with climate variability over Lake Victoria Basin in East Africa. Mon. Wea. Rev., 134, 3588-3609.

Baldauf, M., 2008: Stability analysis for linear discretisations of the advection equation with Runge-Kutta time integration. J. Comput. Phys., 227, 6638-6659.

- , and J. P. Schulz, 2004: Prognostic precipitation in the LokalModell (LM) of DWD. COSMO Newsletter, No. 4, 177-180. [Available online at http://www.cosmo-model.org/content/ model/documentation/newsLetters/newsLetter04/default. htm.]

— A. Seifert, J. Förstner, D. Majewski, M. Raschendorfer, and T. Reinhardt, 2011: Operational convective-scale numerical weather prediction with the COSMO model: Description and sensitivities. Mon. Wea. Rev., 139, 3887-3905.

Benoit, R., J. Côté, and J. Mailhot, 1989: Inclusion of a TKE boundary layer parameterization in the Canadian regional finite-element model. Mon. Wea. Rev., 117, 1726-1750.

Black, E., J. Slingo, and K. R. Sperber, 2003: An observational study of the relationship between excessively strong short rains in the coastal East Africa and Indian Ocean SST. Mon. Wea. Rev., 131, 74-94.

Bougeault, P., 1985: A simple parameterization of the large-scale effects of cumulus convection. Mon. Wea. Rev., 113, 21082121.

Buzzi, M., M. W. Rotach, M. Raschendorfer, and A. A. M. Holtslag, 2011: Evaluation of the COSMO-SC turbulence scheme in a shear-driven stable boundary layer. Meteor. Z., 20, 335-350.

Christensen, O. B., M. Drews, and J. H. Christensen, 2006: The HIRHAM regional climate model version 5. DMI Tech. Rep. 06-17, 22 pp.

Clark, C. O., P. J. Webster, and J. E. Cole, 2003: Interdecadal variability of the relationship between the Indian Ocean zonal mode and East African coastal rainfall anomalies. J. Climate, 16, 548-554.

Cuxart, J., P. Bougeault, and J.-L. Redelsperger, 2000: A turbulence scheme allowing for mesoscale and large-eddy simulations. Quart. J. Roy. Meteor. Soc., 126, 1-30.

Delage, Y., 1997: Parameterising sub-grid scale vertical transport in atmospheric models under statically stable conditions. Bound.-Layer Meteor., 82, 23-48.

Denis, B., R. Laprise, D. Caya, and J. Côté, 2002: Downscaling ability of one-way nested regional climate models: The
Big-Brother Experiment. Climate Dyn., 18, 627-646, doi:10.1007/s00382-001-0201-0.

Déqué, M., 2010: Regional climate simulation with a mosaic of RCMs. Meteor. Z., 19, 259-266.

Dickinson, R. E., A. Henderson-Sellers, and P. J. Kennedy, 1993: Biosphere-Atmosphere Transfer Scheme (BATS) version 1E as coupled to the NCAR Community Climate Model. NCAR Tech. Rep. NCAR/TN-387+STR, 72 pp.

Diro, G. T., D. Grimes, and E. Black, 2011: Teleconnections between Ethiopian summer rainfall and sea surface temperature: Part I-Observation and modelling. Climate Dyn., 37, 103119, doi:10.1007/s00382-010-0837-8.

_ A. M. Tompkins, and X. Bi, 2012: Dynamical downscaling of ECMWF ensemble seasonal forecasts over East Africa with RegCM3. J. Geophys. Res., 117, D16103, doi:10.1029/ 2011JD016997.

Doms, G., J. Förstner, E. Heise, H.-J. Herzog, M. Raschendorfer, R. Schrodin, T. Reinhardt, and G. Vogel, 2007: A description of the nonhydrostatic regional model LM (version 3.20). Part II: Physical parameterization. COSMO Consortium, 154 pp. [Available online at http://www.cosmo- model. org/content/model/documentation/core/cosmoPhysParamtr. pdf.]

Douville, H. S., J. F. Planton, D. B. Royer, S. Stephenson, L. Tyteca, S. Kergoat, R. A. Lafont, and R. A. Betts, 2000: Importance of vegetation feedbacks in doubled- $\mathrm{CO}_{2}$ climate experiments. J. Geophys. Res., 105, 14841-14861.

Dudhia, J., 1989: Numerical study of convection observed during the winter monsoon experiment using a mesoscale twodimensional model. J. Atmos. Sci., 46, 3077-3107.

ECMWF, 2006: IFS documentation-Cy31r1 Operational implementation PART IV: Physical processes. ECMWF, 155 pp. [Available online at http://www.ecmwf.int/research/ifsdocs/ CY31r1/PHYSICS/IFSPart4.pdf.]

Edwards, J. M., and A. Slingo, 1996: Studies with a flexible new radiation code. I: Choosing a configuration for a large-scale model. Quart. J. Roy. Meteor. Soc., 122, 689-719.

Essery, R. L. H., M. J. Best, R. A. Betts, and P. M. Cox, 2003: Explicit representation of subgrid heterogeneity in a GCM land surface scheme. J. Hydrometeor., 4, 530-543.

Favre, A., D. Stone, R. Cerezo, N. Philippon, and B. Abiodun, 2011: Diagnostic of monthly rainfall from CORDEX simulations over Africa: Focus on the annual cycles. Proc. Int. Conf. on the Coordinated Regional Climate Downscaling ExperimentCORDEX, Trieste, Italy, World Climate Research Program. [Available online at http://indico.ictp.it/indico/getFile.py/ access ? resId $=3 \&$ materialId $=1 \& \operatorname{confId}=\mathrm{a} 10131$.]

FEWS NET, cited 2011: Past year one of the driest on record in the eastern Horn. Famine Early Warning System Network Report, 14 June 2011, U.S. Agency for International Development. [Available online at http://reliefweb.int/report/ ethiopia/east-africa-past-year-one-driest-record-eastern-hornjune-14-2011.]

Fouquart, Y., and B. Bonnel, 1980: Computations of solar heating of the earth's atmosphere: A new parameterization. Beitr. Phys. Atmos., 53, 35-62.

Fritsch, J. M., and C. F. Chappell, 1980: Numerical prediction of convectively driven mesoscale pressure systems. Part I: Convective parameterization. J. Atmos. Sci., 37, 1722-1733.

Giorgetta, M., and M. Wild, 1995: The water vapour continuum and its representation in ECHAM4. MPI Rep. 162, 38 pp.

Giorgi, F., and M. R. Marinucci, 1996: An investigation of the sensitivity of simulated precipitation to model resolution and 
its implications for climate studies. Mon. Wea. Rev., 124, 148166.

—, and L. O. Mearns, 1999: Introduction to special section: Regional climate modeling revisited. J. Geophys. Res., 104, 6335-6352, doi:10.1029/98JD02072.

— - M. R. Marinucci, and G. T. Bates, 1993a: Development of a second-generation regional climate model (RegCM2). Part I: Boundary-layer and radiative transfer processes. Mon. Wea. Rev., 121, 2794-2813.

$\longrightarrow, \ldots, \ldots$, and G. De Canio, 1993b: Development of a second-generation regional climate model (RegCM2). Part II: Convective processes and assimilation of lateral boundary conditions. Mon. Wea. Rev., 121, 2814-2832.

— C. Jones, and G. R. Asrar, 2009: Addressing climate information needs at the regional level: The CORDEX framework. WMO Bull., 58, 175-183.

Gissila, T., E. Black, D. I. F. Grimes, and J. M. Slingo, 2004: Seasonal forecasting of the Ethiopian summer rains. Int. J. Climatol., 24, 1345-1358, doi:10.1002/joc.1078.

Gregory, D., and P. R. Rowntree, 1990: A mass flux convection scheme with representation of cloud ensemble characteristics and stability-dependent closure. Mon. Wea. Rev., 118, 1483 1506.

— and S. Allen, 1991: The effect of convective downdraughts upon NWP and climate simulations. Preprints, Ninth Conf. on Numerical Weather Prediction, Denver, CO, Amer. Meteor. Soc., 122-123.

Grell, G. A., 1993: Prognostic evaluation of assumptions used by cumulus parameterizations. Mon. Wea. Rev., 121, 764-787.

Hagemann, S., 2002: An improved land surface parameter dataset for global and regional climate models. MPI Rep. 336, $21 \mathrm{pp}$.

Hastenrath, S., A. Nicklis, and L. Greischar, 1993: Atmospherichydrospheric mechanisms of climate anomalies in the western equatorial Indian Ocean. J. Geophys. Res., 98 (C11), 20219 20235.

Herzog, H. J., G. Vogel, and U. Schubert, 2002: LLM-A nonhydrostatic model applied to high-resolving simulations of turbulent fluxes over heterogeneous terrain. Theor. Appl. Climatol., 73, 67-86.

Holtslag, A. A. M., E. I. F. De Bruin, and H. L. Pan, 1990: A highresolution air mass transformation model for short-range weather forecasting. Mon. Wea. Rev., 118, 1561-1575.

Hong, S.-Y., J. Dudhia, and S.-H. Chen, 2004: A revised approach to ice microphysical processes for the bulk parameterization of clouds and precipitation. Mon. Wea. Rev., 132, 103-120.

_- Y. Y. Noh, and J. Dudhia, 2006: A new vertical diffusion package with an explicit treatment of entrainment processes. Mon. Wea. Rev., 134, 2318-2341.

Indeje, M., H. M. F. Semazzi, and J. L. Ogallo, 2000: ENSO signal in East African rainfall seasons. Int. J. Climatol., 20, 19-46.

Jacob, D., 2001: A note to the simulation of the annual and interannual variability of the water budget over the Baltic Sea drainage basin. Meteor. Atmos. Phys., 77, 61-73.

__ , and Coauthors, 2007: An inter-comparison of regional climate models for Europe: Model performance in present-day climate. Climatic Change, 81, 31-52.

Jones, R. G., M. Noguer, D. Hassel, D. Hudson, S. Wilson, G. Jenkins, and J. Mitchell, 2004: Generating high resolution climate change scenarios using HadRM3P. Met Office Hadley Centre Rep., 40 pp.

Kain, J. S., 2004: The Kain-Fritsch convective parameterization: An update. J. Appl. Meteor., 43, 170-181.
—_, and J. M. Fritsch, 1990: A one-dimensional entraining/ detraining plume model and its application in convective parameterization. J. Atmos. Sci., 47, 2784-2802.

$\longrightarrow$, and 1993: Convective parameterization for mesoscale models: The Kain-Fritsch scheme. The Representation of Cumulus Convection in Numerical Models, Meteor. Monogr., No. 46, Amer. Meteor. Soc., 165-170.

Kiehl, J. T., J. J. Hack, G. B. Bonan, B. A. Boville, B. P. Briegleb, D. L. Williamson, and P. J. Rasch, 1996: Description of the NCAR Community Climate Model (CCM3). NCAR Tech. Note NCAR/TN-420+STR, 152 pp.

Korecha, D., and A. G. Barnston, 2007: Predictability of June to September rainfall in Ethiopia. Mon. Wea. Rev., 135, 628650.

Kuo, H. L., 1965: On formation and intensification of tropical cyclones through latent heat release by cumulus convection. J. Atmos. Sci., 22, 40-63.

Li, J., and H. W. Barker, 2005: A radiation algorithm with correlated- $k$ distribution. Part I: Local thermal equilibrium. J. Atmos. Sci., 62, 286-309.

Lohmann, U., and E. Roeckner, 1996: Design and performance of a new cloud microphysics scheme developed for the ECHAM general circulation model. Climate Dyn., 12, 557-572.

Louis, J.-F., 1979: A parametric model of vertical eddy fluxes in the atmosphere. Bound.-Layer Meteor., 17, 187-202.

Mellor, G. L., and T. Yamada, 1982: Development of a turbulence closure model for geophysical fluid problems. Rev. Geophys. Space Phys., 20, 851-875.

Meyers, G., P. McIntosh, L. Pigot, and M. Pook, 2007: The years of El Niño, La Niña, and interactions with the tropical Indian Ocean. J. Climate, 20, 2872-2880.

Mitchell, T. D., and P. D. Jones, 2005: An improved method of constructing a database of monthly climate observations and associated high-resolution grids. Int. J. Climatol., 25, 693-712.

Mlawer, E. J., S. J. Taubman, P. D. Brown, M. J. Iacono, and S. A. Clough, 1997: Radiative transfer for inhomogeneous atmospheres: RRTM, a validated correlated- $k$ model for the longwave. J. Geophys. Res., 102, 16663-16682.

Morcrette, J.-J., 1990: Impact of changes to the radiation transfer parameterizations plus cloud optical properties in the ECMWF model. Mon. Wea. Rev., 118, 847-873.

_ L. L. Smith, and Y. Fouquart, 1986: Pressure and temperature dependence of the absorption in longwave radiation parametrizations. Beitr. Phys. Atmos., 59, 455-469.

Mpeta, E., 2002: Mechanisms of inter-annual rainfall variability over tropical highlands of Africa and its predictability potential. Ph.D. thesis, University of Zululand, 198 pp.

Mutemi, J. N., 2003: Climate anomalies over eastern Africa associated with various ENSO evolution phases. Ph.D. thesis, University of Nairobi.

Nicholson, S. E., 1996: A review of climate dynamics and climate variability in eastern Africa. The Limnology, Climatology and Paleoclimatology of the East African Lakes, T. Johnson and E. Odada, Eds., CRC Press, 25-56.

-, and J. Kim, 1997: The relationship of the El Niño-Southern Oscillation to African rainfall. Int. J. Climatol., 17, 117-135.

Nikulin, G., and Coauthors, 2012: Precipitation climatology in an ensemble of CORDEX-Africa regional climate simulations. J. Climate, 25, 6057-6078.

Nyakwada, W., 2009: Predictability of East African seasonal rainfall with sea surface temperature gradient modes. Ph.D. dissertation, University of Nairobi, 265 pp. 
Ogallo, L. J., 1988: Relationships between seasonal rainfall in East Africa and the Southern Oscillation. J. Climatol., 8, 31-43, doi:10.1002/joc.3370080104.

Omondi, P., L. A. Ogallo, R. Anyah, J. M. Muthama, and J. Ininda, 2013: Linkages between global sea surface temperatures and decadal rainfall variability over the eastern Africa region. Int. J. Climatol., 33, 2082-2104.

Paeth, H., and Coauthors, 2011: Progress in regional downscaling of West African precipitation. Atmos. Sci. Lett., 12, 75-82, doi:10.1002/asl.306

Pal, J. S., E. E. Small, and E. A. B. Eltahir, 2000: Simulation of regional-scale water and energy budgets: Representation of subgrid cloud and precipitation processes within RegCM. J. Geophys. Res., 105, 29579-29594.

—, and Coauthors, 2007: Regional climate modeling for the developing world: The ICTP RegCM3 and RegCNET. Bull. Amer. Meteor. Soc., 88, 1395-1409.

Rasch, P. J., and J. E. Kristjánsson, 1998: A comparison of the CCM3 model climate using diagnosed and predicted condensate parameterizations. J. Climate, 11, 1587-1614.

Rechid, D., T. J. Raddatz, and D. Jacob, 2009: Parameterization of snow-free land surface albedo as a function of vegetation phenology based on MODIS data and applied in climate modelling. Theor. Appl. Climatol., 95, 245-255.

Ricard, J. L., and J. F. Royer, 1993: A statistical cloud scheme for use in an AGCM. Ann. Geophys., 11, 1095-1115.

Ritter, B., and J.-F. Geleyn, 1992: A comprehensive radiation scheme of numerical weather prediction with potential applications in climate simulations. Mon. Wea. Rev., 120, 303-325.

Rockel, B., A. Will, and A. Hense, 2008: The regional climate model COSMO-CLM (CCLM). Meteor. Z., 17, 347-348.

Ropelewski, C. F., and M. S. Halpert, 1987: Global and regional scale precipitation patterns associated with the El Niño/ Southern Oscillation. Mon. Wea. Rev., 115, 1606-1626.

$\longrightarrow$, and — 1989: Precipitation patterns associated with the high index phase of the Southern Oscillation. J. Climate, 2, 268-284.

Rudolf, B., A. Becker, U. Schneider, A. Meyer-Christoffer, and M. Ziese, 2010: The new "GPCC Full Data Reanalysis Version 5" providing high-quality gridded monthly precipitation data for the global land-surface is public available since December 2010. GPCC Status Rep., 7 pp.

Rummukainen, M., 2010: State-of-the-art with regional climate model. Wiley Interdiscip. Rev.: Climate Change, 1, 82-96, doi:10.1002/wcc.8.

Saji, N. H., B. N. Goswami, P. N. Vinayachandran, and T. Yamagata, 1999: A dipole mode in the tropical Indian Ocean. Nature, 401, 360-363, doi:10.1038/43855.

Samuelsson, P., S. Gollvik, and A. Ullerstig, 2006: The land-surface scheme of the Rossby Centre Regional Atmospheric Climate Model (RCA3). Swedish Meteorological and Hydrological Institute Meteorology Rep. 122, 25 pp.

- , and Coauthors, 2011: The Rossby Centre Regional Climate Model RCA3: Model description and performance. Tellus, 63A, 4-23.

Sass, B. H., L. Rontu, H. Savijärvi, and P. Räisänen, 1994: HIRLAM-2 radiation scheme: Documentation and tests. SMHI HIRLAM Tech. Rep. 16, 43 pp.

Savijärvi, H., 1990: Fast radiation parameterization schemes for mesoscale and short-range forecast models. J. Appl. Meteor., 29, 437-447.

Schulz, J.-P., L. Dümenil, J. Polcher, C. A. Schlosser, and Y. Xue, 1998: Land surface energy and moisture fluxes: Comparing three models. J. Appl. Meteor., 37, 288-307.
Segele, Z. T., L. M. Leslie, and P. J. Lamb, 2009a: Evaluation and adaptation of a regional climate model for the Horn of Africa: Rainfall climatology and interannual variability. Int. J. Climatol., 29, 47-65.

_ _ P. J. Lamb, and L. M. Leslie, 2009b: Large-scale atmospheric circulation and global sea surface temperature associations with Horn of Africa June-September rainfall. Int. J. Climatol., 29, 1075-1100, doi:10.1002/joc.1751.

Shongwe, M. E., G. J. Van Oldenborgh, B. J. J. M. Van Den Hurk, B. De Boer, C. A. S. Coelho, and M. K. Van Aalst, 2009: Projected changes in mean and extreme precipitation in Africa under global warming. Part I: Southern Africa. J. Climate, 22, 3819-3837.

Skamarock, W. C., J. B. Klemp, J. Dudhia, D. O. Gill, D. M. Barker, W. Wang, and J. G. Powers, 2008: A description of the Advanced Research WRF version 3. NCAR Tech Note NCAR/TN-475+STR, 113 pp.

Smirnova, T. G., J. M. Brown, S. G. Benjamin, and D. Kim, 2000: Parameterization of cold-season processes in the MAPS landsurface scheme. J. Geophys. Res., 105, 4077-4086.

Smith, R. N. B., 1990: A scheme for predicting layer clouds and their water content in a general circulation model. Quart. J. Roy. Meteor. Soc., 116, 435-460.

Sun, L., F. H. M. Semazzi, F. Giorgi, and L. Ogallo, 1999a: Application of the NCAR regional climate model to eastern Africa: 1. Simulation of the short rains of 1988. J. Geophys. Res., 104, 6529-6548.

,,,--- and $-1999 \mathrm{~b}$ : Application of the NCAR regional climate model to eastern Africa: 2. Simulation of interannual variability of short rains. J. Geophys. Res., 104, 6549-6562.

- D. F. Moncunill, H. Li, A. D. Moura, F. D. A. D. S. Filho, and S. E. Zebiak, 2006: An operational dynamical downscaling prediction system for Nordeste Brazil and the 2002-04 realtime forecast evaluation. J. Climate, 19, 1990-2007.

Sundqvist, H., E. Berge, and J. E. Kristjansson, 1989: Condensation and cloud parameterization studies with a mesoscale numerical weather prediction model. Mon. Wea. Rev., 117, 1641-1657.

Sylla, M. B., F. Giorgi, E. Coppola, and L. Mariotti, 2012: Uncertainties in daily rainfall over Africa: Assessment of gridded observation products and evaluation of a regional climate model simulation. Int. J. Climatol., 33, 1805-1817, doi:10.1002/ joc.3551.

Taylor, K. E., 2001: Summarizing multiple aspects of model performance in a single diagram. J. Geophys. Res., 106 (D7), 7183-7192.

Tiedtke, M., 1989: A comprehensive mass flux scheme for cumulus parameterization in large-scale models. Mon. Wea. Rev., 117, 1779-1800.

_ 1993: Representation of clouds in large-scale models. Mon. Wea. Rev., 121, 3040-3061.

Tompkins, A. M., 2002: A prognostic parameterization for the subgrid-scale variability of water vapor and clouds in largescale models and its use to diagnose cloud cover. J. Atmos. Sci., 59, 1917-1942.

Ummenhofer, C. C., M. H. England, P. C. McIntosh, G. A. Meyers, M. J. Pook, J. S. Risbey, A. Sen Gupta, and A. S. Taschetto, 2009: What causes southeast Australia's worst droughts? Geophys. Res. Lett., 36, L04706, doi:10.1029/2008GL036801.

UNEP, 2011: The Democratic Republic of the Congo: Post-conflict environmental assessment synthesis for policy makers. United Nations Environment Programme, $72 \mathrm{pp}$.

van Meijgaard, E., L. van Ulft, W. van den Berg, F. Bosveld, B. van den Hurk, G. Lenderink, and A. P. Siebesma, 2008: The 
KNMI regional atmospheric climate model RACMO, version 2.1. KNMI Tech. Rep. TR-302, 43 pp.

Verseghy, D. L., 2000: The Canadian Land Surface Scheme (CLASS): Its history and future. Atmos.-Ocean, 38, 1-13.

Wang, Y., R. L. Leung, J. L. McGregor, D.-K. Lee, W.-C. Wang, Y. Ding, and F. Kimura, 2004: Regional climate modeling: Progress, challenges, and prospects. J. Meteor. Soc. Japan, 82, 1599-1628.
Wilson, C. A., 1992: Vertical diffusion. Unified Model Documentation Paper 21, Met Office, 4 pp. [Available online at http:// cms.ncas.ac.uk/documents/vn4.5/p021.pdf.]

World Bank, 2012: Doing business in the East African economies. IFC/World Bank Rep., 116 pp.

Zadra, A., D. Caya, J. Côté, B. Dugas, C. Jones, R. Laprise, K. Winger, and L.-P. Caron, 2008: The next Canadian Regional Climate Model. Phys. Can., 64, 75-83. 